\title{
Land Conversion Dynamics in the Borana Rangelands of Southern Ethiopia: An Integrated Assessment Using Remote Sensing Techniques and Field Survey Data
}

\section{Michael Elias ${ }^{1, *}$, Oliver Hensel ${ }^{1}$, Uwe Richter ${ }^{1}$, Christian Hülsebusch ${ }^{2}$, Brigitte Kaufmann ${ }^{2}$ and Oliver Wasonga ${ }^{3}$}

1 Department of Agricultural Engineering, University of Kassel, Nordbahnhofstr. 1a, D-37213

Witzenhausen, Germany; E-Mails: agrartechnik@uni-kassel.de (O.H.); judge@uni-kassel.de (U.R.)

2 German Institute for Tropical and Subtropical Agriculture (DITSL), GmbH, Steinstraße 19, D-37213, Witzenhausen, Germany; E-Mails: c.huelsebusch@ditsl.org (C.H.); b.kaufmann@ditsl.org (B.K.)

3 Department of Land Resource Management and Agricultural Technology, University of Nairobi, P.O. Box 29053, Nairobi 00625, Kenya; E-Mail: oliverwasonga@gmail.com or oliverwasonga@uonbi.ac.ke

* Author to whom correspondence should be addressed; E-Mail: mgalulamike@yahoo.com; Tel.: +49-5542-98-1685 (ext. 1685); Fax: +49-5542-98-1520.

Received: 23 August 2014 / Accepted: 24 December 2014 / Published: 7 January 2015

\begin{abstract}
Conversion of rangelands into cultivated land is one of the main challenges affecting the management of rangelands in Ethiopia. In order to inform policy makers about trends in land-use conversion, this study examined the drivers, trends, and impacts of land conversions in five locations selected in the Borana rangelands of Southern Ethiopia. This study integrated survey interviews from agro-pastoralists, participatory appraisals, rainfall data, and remotely sensed satellite data from Landsat images taken in 1985 and 2011. Results indicate that there is a marked increase in cultivated land in some of the study sites while in the other sites there is a slight reduction. The bare lands increased in some parts of the study sites though there was slight recovery of grassland in some of the degraded areas. Settlement areas with permanent housing increased. Woodland vegetation decreased except on mountain escarpments where there were slight gains. The results further show that, during this period, bushland decreased while at the same time grassland increased. Shrub/grassland with seasonally flooded areas increased in the bottomlands. Inhabitants interviewed in the study areas perceived land use and land cover changes to be driven by interplay of recurrent drought, loss of pasture, food insecurity, and decline in
\end{abstract}


income. Changes in policies that govern natural resources have influence the land use change in this area and the expansion of cultivation. Expansion of cultivation practices upon rangelands has resulting in significant loss of vegetation biomass and soil erosion, thereby precipitating rangeland degradation. The results provide comprehensive insights regarding the influence of internal and external drivers of land conversion that should be considered when making decisions for land use planning.

Keywords: land cover change; drivers; crop cultivation; remote sensing; rangeland ecosystem

\section{Introduction}

Conversions of land from one use to another have become recognized as major causes of global environmental changes [1,2]. It is, therefore, important to understand the drivers and trends influencing these conversions as a prerequisite for analysis of land use and land cover change processes $[3,4]$. Knowledge of the drivers and the trends of land conversion are needed for local, regional, and global assessments because land conversion affects ecosystem processes (carbon stocks, biodiversity, vegetation, and water) and the livelihoods of inhabitants are under threat [5]. Earlier studies have shown that land conversion in Africa's rangelands is attributed to inefficient policies that govern natural resources [6], and that increasing anthropogenic activities such as grazing and cultivation [7]. [8], distinguish the effects of the rainfall patterns and human activities on the degradation of rangelands. They also have analyzed the effects of variable climate conditions on vegetation changes in the Sahel [9]. These studies have demonstrated that both human and climatic factors have potential influences on land conversion. One of the dominant contemporary forms of land conversion in Africa's rangelands is the expansion of cultivation [10-12]. Small-scale crop cultivation is regarded as a livelihood diversification option to cope with economic hardships, but the process has negative impacts on ecosystem integrity.

In Ethiopia, the conversion of rangelands into cultivated land has been reported [13,14], but the driving factors behind the on-going processes have not been thoroughly investigated. Specifically, the Borana pastoralists of Southern Ethiopia have been appreciated for their superior systems of rangeland resource use and management for a long time [15,16], however, the prior communal management systems have been weakened over time. Alongside this, there has been increasing crop cultivation in some portions of the rangelands [17]. Despite the fact that small-scale crop cultivation is an age-old practice of diversifying asset portfolios among pastoral communities inhabiting the precarious rangelands of Ethiopia [18], the negative trade-offs associated with its adoption, especially on contemporary scales, have adverse implications for the very livelihoods of these people and for the ecosystem. A previous study by [17] investigated the association between poverty and the participation of Borana herders in cultivation and [19] analyzed current trends in cattle management, rangeland degradation, and the perceptions of pastoralists. However, not many of the drivers behind the expansion of cultivation in the rangeland have been examined, except for in the case of [20] who analyzed livelihood diversifications in the Borana rangeland. There is a paucity of evidence regarding 
the drivers, trends, and impacts of on-going land conversions. Analyzing these variables will inform policy makers and rangeland managers of the extent to which land conversion affects the ecosystem.

Alongside this, a better way to understand the drivers, trends, and impacts requires an integrative approach, i.e., socio-economic and biophysical processes [3]. Since the drivers of land conversion are not uniform, case study evidence remains crucial for gaining broad insight into how socio-environmental interactions within specific contexts influence land conversions and how the processes can lead to global impacts [5]. This is necessary for guiding decisions and policies on land use and the sustainability of ecosystems. It is against this background that this study was conducted to examine the drivers and trends in land conversion using integrated methods of remote sensing and field survey data.

Earlier studies [21,22] have documented the benefits of remote sensing and geographic information systems (GIS) for tracing and analyzing land cover changes. Remote sensing and GIS are suitable for deriving quantitative information regarding spatial and temporal land cover changes. Besides remote sensing techniques, understanding the impact of the socio-economic dimension on land conversion remains crucial for land cover change studies [5]. For example, [23], demonstrates a methodological context for analyzing ecological dynamics by combining demography, local community perceptions, and socio-ecological systems. The authors provide empirical evidence on the trade-offs between socio-economic concerns and the environment in assessing ecological dynamics. In this study, we integrated remotely sensed satellite data, rainfall data, and social economic data to investigate land conversion dynamics.

The objective of this study is to examine the drivers, trends, and impacts of land conversion dynamics in selected sites of the Borana rangelands. The specific objectives are: (a) to assess temporal trends in the expansion of cultivation and the resulting land cover changes between February 1985 and February 2011, (b) to analyze the social economic factors and their influences on the expansion of cultivation, (c) to understand the drivers behind the expansion of cultivation, and (d) to analyze the implications of land management on the rangeland ecosystems. The results of this study have the potential to improve scientific knowledge of the drivers behind land conversion. The study demonstrates the importance of integrating multiple data sources in analyzing land conversion dynamics. The findings are expected to guide decisions and to inform policy makers about the current status of land uses and land cover changes, which are very crucial in resource management in the arid and semi-arid rangelands.

\section{Materials and Methods}

\subsection{The Study Areas}

The administrative division of the Federal Democratic Republic of Ethiopia divides the regional states into divisions called Woreda. A Woreda is an administrative division equivalent to a district. It is composed of a number of subdivisions, which are the smallest units of local government, called Kebele. In this study, a Kebele refers to a pastoral area (PA) within a Woreda. The study was conducted in five Kebele located in the Borana rangelands in the Southern part of Ethiopia. The total land area of the study sites is $735.90 \mathrm{~km}^{2}$. One study site, Darito, is located in the Yabelo Woreda. The other four study sites, Soda, Samaro, Haralo, and Did mega are all located around Mega in Dire 
Woreda. The study sites lie within $4^{\circ} 45^{\prime} 20^{\prime \prime} \mathrm{N}$ and $4^{\circ} 5^{\prime} 20^{\prime \prime} \mathrm{N}$ and 38 $22^{\prime} 40^{\prime \prime} \mathrm{E}$ and $38^{\circ} 9^{\prime} 20^{\prime \prime} \mathrm{E}$ (Figure 1). The landscapes of the study areas are characterized by low-lying flat terrain, rolling hills, and steeply dissected mountains ranging from 1090 to $2204 \mathrm{~m}$ above sea level. The region has a bimodal rainfall pattern with 'short rain' occurring between September to December and 'long rain' falling from March to May. The average annual rainfall ranges between $100 \mathrm{~mm}$ and $600 \mathrm{~mm}$, and the mean annual temperature ranges from $15{ }^{\circ} \mathrm{C}$ to $24{ }^{\circ} \mathrm{C}[15,24]$. The major soil types in the study areas developed from a geological formation of $40 \%$ quaternary deposit, $38 \%$ basement complex formation, and $20 \%$ volcanic deposit [25]. In the lowland areas of the rangelands, soil drainage is inundated, resulting in occasional water-logging or floods. The common vegetation types include Acacia spp, Boscia mossambicensis, Combretum molle, Commiphora schimperi, Cordia africana, Croton macrostachyus, Erythrina melanacantha, Euphorbia tirucalli, Ficus sycomorus, Terminalia brownii, Terminalia prunioides, Juniperus procera, Rhamnus prinoides, Balanites aegyptiaca and Olea europaea subsp. cuspidate [15].

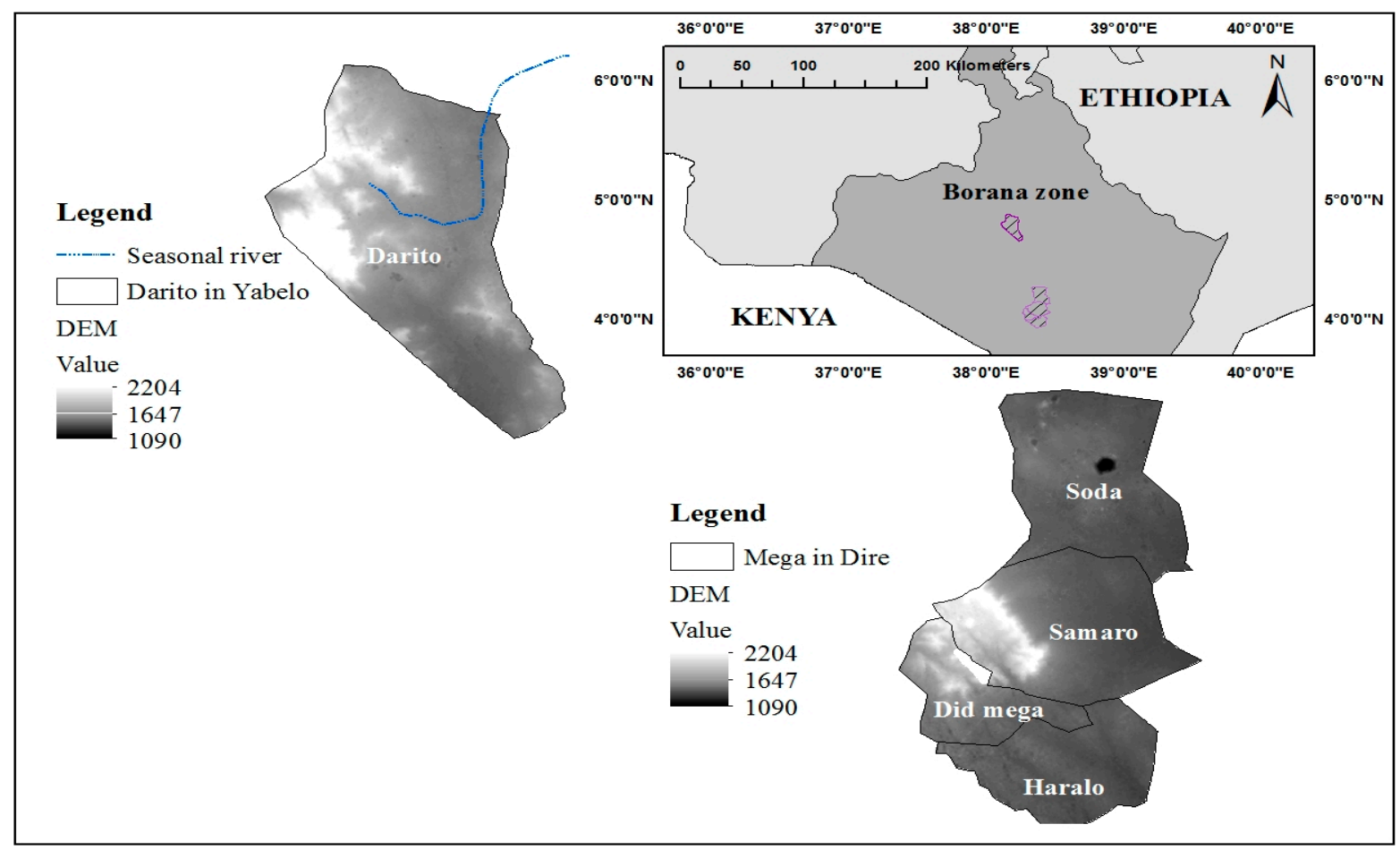

Figure 1. Study sites.

\subsection{Data Collected for Land Use and Land Cover Classification}

Map resources were two topographical maps of the Yabelo and Dire districts, sheet 0438 A1 for year 1992 and sheet 0434 C4 for year 1993, respectively [26], and shape files of the study sites were obtained from the Ethiopian Mapping Agency (EMA) in Ethiopia. Weather data, such as rainfall data of year 1975 to 2012, was obtained from the Ethiopian Meteorological Agency [27]. The rainfall data was obtained for the purpose of studying the long-term time series of rainfall trend in the study sites. Landsat satellite images for February 1985 and February 2011 were obtained from the USGS Earth Explorer. Fieldwork was carried out to ascertain the land cover type, marking of training sites and to identify the physical characteristics of the land covers (grassland, bushland, woodland, cultivated land, 
and rural settlements, settlement/built up areas and shrub/grassland with seasonal floods). A handheld Trimble GeoXT 2005 and a Garmin eTrex 10 GPS were used to collect ground coordinates and waypoints. The GPS devices were configured to World Geodetic System 1984 (WGS 84) and Universal Traverse Mercator (UTM) zone 37N specific to Ethiopia. Auxiliary data collected were important for training and validation purposes of land cover classification. In each land cover type, about a hundred training sites were marked. Other training sites were marked for water points and for the main roads for ground truthing. Two Landsat TM imageries acquired in February 1985 and February 2011 were used for land cover classification. These years were chosen because of the availability of data, the quality of the images and in February there were no clouds. Analysis was processed using ArcGIS 10.2 and supplemented by Quantum GIS 1.8.0 and Monteverdi 1.12.0 software. The images were rectified to the World Geodetic System 1984 (WGS 84) and Universal Traverse Mercator (UTM) zone $37 \mathrm{~N}$ specific to Ethiopia. The pre-processing procedures recommended in [28], clipping the region of interest (ROI) and using color composites with different reflectance bands $(4,3$, and 2), were used to improve visualization and interpretation. Land cover classification was done separately in all five Kebele for the purpose of comparing the differences.

\subsection{Socio-Economic Data Collected}

Social economic data collected included the age of each head of household, gender, income, livelihood activities, and land ownership. This information was collected for the purpose of quantifying the socio-economic activities of the inhabitants in the study sites and to compare their influence on land conversion. Participatory tools, such as focus group discussions (FGDs), key informant interviews, resource mapping and transect walks, were used to collect data. Numerous social groups, such as elders, women leaders, natural resource experts, vegetation ecologists, Kebele chairpersons, pastoralist and agro-pastoralist leaders, and development agency officials from the respective Kebele, were key informants who participated in the research. A specific checklist of questions was used to interview the key participants (development agencies, government officials, and Kebele leaders). Focus group discussions using semi-structured interviews were held, and the participants were from the following social groups: Kebele elders (men and women), youths, natural resource experts, vegetation ecologists, Kebele chairpersons, pastoralist and agro-pastoralist leaders, and development agency officials. The discussion was used as a means of creating awareness in the agro-pastoralists community, generating ideas regarding issues related to land management and mapping the distribution of resources. A household questionnaire survey was administered in the five communities and a total of 265 heads of households were interviewed. A questionnaire composed of structured and unstructured questions was used during the interviews. In order to obtain a representative sample, stratified and clustered sampling methods were used to ensure that data collected represented the communities studied. Clustering of households was necessary because the pastoralists do not live in nuclear settlements but are scattered. 


\subsection{Data Analysis}

\subsubsection{Land Cover Classification and Change Detection}

The maximum likelihood approach of the unsupervised classification method was used for the analyses. The software grouped the pixels based on the reflectance properties of the pixels to create clusters. This approach was used because it has the advantages of recognizing unique classes, reduces human error, and does not require great knowledge of the area.

Table 1. Description of the criteria used to classify land use and land cover type.

\begin{tabular}{ll}
\hline Land Use/Cover Class & Description \\
\hline Woodland & Land covered with vegetation species (plants higher than 5 m to 20 m classified as \\
& woodland trees \\
Bushland & Land composed of bush or shrubs (plants lower than 5 m are classified as bushland) \\
Grassland & Land cover dominated by grass and herbs with scattered trees and shrubs \\
Cultivated land & Crop fields with rural settlements \\
Bare land & Non vegetative land such as rock, sand and lava \\
Shrub/Grassland with & Semi-permanent and seasonal water logged land with less than 10\% of vegetation cover \\
seasonal floods & (flood plains comprised of herbs, grass and dwarf bushes) \\
Settlement/Built up area & Permanent settlement areas with more than 2000 inhabitants \\
\hline
\end{tabular}

Based on [29] land-use land-cover classification system, seven land cover classes, bare land, cultivated land and rural settlements, settlements/built up areas, shrub/grassland with seasonal floods, woodland, grassland, and bushland, were classified in accordance with [30,31] classification criteria for East African rangelands. With a spatial resolution of $30 \mathrm{~m} \times 30 \mathrm{~m}$ for Landsat images it was not possible to classify rural settlements under one separate class because the roofs of most houses were grass thatched and thus caused spectral mixture with other covers. It was, therefore, decided to classify cultivated land and scattered settlements under one class. Nevertheless, settlements covered with galvanized iron sheets were classified. Change detection analysis was carried out using ArcGIS10.2 by comparing two classified land cover maps, i.e., land cover for 1985 and 2011. The summaries of the areas and percentages of land cover change are presented in Tables 2 and 3. Accuracy assessment was done using ERDAS IMAGINE 2011 software by comparing the classified land cover maps with high resolution images from Google Earth and the training sites generated during field data collection.

\subsubsection{Socio-Demographic and Economic Profile of the Respondents}

Social economic data from respondents' interviews were analyzed using descriptive statistics in the Statistical Package for Social Sciences (SPSS) and QED Statistics computer software. A statistical test, i.e., Chi-square $\left(X^{2}\right)$, was used to test the differences among family size and size of land, the proportion of Kebele demanding land periodically and the differences in existence of school-going children. Mean comparison was used to check the differences in income, family size, and school-going children. The spatial and temporal trends in increasing number of agro-pastoralists, the drivers behind the expansion of cultivation, ranked income sources, economic activities, and land management practices were analyzed using descriptive statistics such as means, standard deviations, and percentages. 
Table 2. Summary of the land cover classes and land cover changes in Darito Kebele.

\begin{tabular}{|c|c|c|c|c|c|c|}
\hline \multirow{3}{*}{ Land Cover Classes } & \multicolumn{4}{|c|}{ Land Cover } & \multirow{2}{*}{\multicolumn{2}{|c|}{$\begin{array}{c}\text { Land Cover change } \\
1985-2011\end{array}$}} \\
\hline & \multicolumn{2}{|c|}{1985} & \multicolumn{2}{|c|}{2011} & & \\
\hline & Area (ha) & $\%$ & Area (ha) & $\%$ & Area (ha) & $\%$ \\
\hline Bare land & 0 & 0 & 364 & 1.60 & 364 & 1.60 \\
\hline Bushland & 10576 & 46.50 & 8293 & 36.46 & -2283 & -10.04 \\
\hline Cultivated land & 1917 & 8.43 & 4758 & 20.92 & 2841 & 12.49 \\
\hline Grassland & 8274 & 36.38 & 7620 & 33.50 & -654 & -2.88 \\
\hline Woodland & 1979 & 8.70 & 1711 & 7.52 & -268 & -1.18 \\
\hline Total & 22746 & 100 & 22746 & 100 & & \\
\hline
\end{tabular}

Table 3. Summary of the land cover classes and land cover changes in Soda, Samaro, Haralo, and Did mega sites.

\begin{tabular}{|c|c|c|c|c|c|c|}
\hline \multirow{3}{*}{ Land Cover Classes } & \multicolumn{4}{|c|}{ Land Cover in Soda } & \multirow{2}{*}{\multicolumn{2}{|c|}{$\begin{array}{c}\text { Land Cover Change } \\
1985-2011 \\
\end{array}$}} \\
\hline & \multicolumn{2}{|c|}{1985} & \multicolumn{2}{|c|}{2011} & & \\
\hline & Area (ha) & $\%$ & Area (ha) & $\%$ & Area (ha) & $\%$ \\
\hline Bare land & 1243 & 7.60 & 523 & 3.20 & -720 & -4.40 \\
\hline Bushland & 8886 & 54.32 & 4428 & 27.07 & -4458 & -27.25 \\
\hline Cultivated land & 1431 & 8.75 & 694 & 4.24 & -737 & -4.51 \\
\hline Shrub/grassland with seasonal floods & 633 & 3.87 & 773 & 4.73 & 140 & 0.86 \\
\hline Grassland & 3881 & 23.73 & 8441 & 52.60 & 4560 & 27.88 \\
\hline Woodland & 284 & 1.74 & 1499 & 9.60 & 1215 & 7.43 \\
\hline \multirow[t]{2}{*}{ Total } & 16358 & 100 & 16358 & 100 & & \\
\hline & \multicolumn{4}{|c|}{ Land Cover in Samaro } & \multicolumn{2}{|c|}{ Land Cover Change } \\
\hline \multirow[t]{2}{*}{ Land Cover Classes } & \multicolumn{2}{|c|}{1985} & \multicolumn{2}{|c|}{2011} & \multicolumn{2}{|c|}{ 1985-2011 } \\
\hline & Area (ha) & $\%$ & Area (ha) & $\%$ & Area (ha) & $\%$ \\
\hline Bare land & 1270 & 7.11 & 1729 & 9.67 & 459 & 2.57 \\
\hline Bushland & 8451 & 47.29 & 4315 & 24.14 & -4136 & -23.14 \\
\hline Cultivated land & 1665 & 9.32 & 1639 & 9.17 & -26 & -0.15 \\
\hline Shrub/grassland with seasonal floods & 2380 & 13.32 & 1932 & 10.81 & -448 & -2.51 \\
\hline Grassland & 2991 & 16.74 & 6924 & 38.74 & 3933 & 22.01 \\
\hline Woodland & 1047 & 5.86 & 1254 & 7.02 & 207 & 1.16 \\
\hline Settlement/Built up Area & 68 & 0.38 & 79 & 0.44 & 11 & 0.06 \\
\hline \multirow[t]{2}{*}{ Total } & 17872 & 100 & 17872 & 100 & & \\
\hline & \multicolumn{4}{|c|}{ Land Cover in Haralo } & Land Cove & hange \\
\hline \multirow[t]{2}{*}{ Land Cover Classes } & \multicolumn{2}{|c|}{1985} & \multicolumn{2}{|c|}{2011} & \multicolumn{2}{|c|}{ 1985-2011 } \\
\hline & Area (ha) & $\%$ & Area (ha) & $\%$ & Area (ha) & $\%$ \\
\hline Bare land & 576 & 5.16 & 2044 & 18.30 & 1468 & 13.14 \\
\hline Bushland & 5813 & 52.04 & 2320 & 20.77 & -3493 & -31.27 \\
\hline Cultivated land & 1231 & 11.02 & 1601 & 14.33 & 370 & 3.31 \\
\hline Shrub/grassland with seasonal floods & 2209 & 19.78 & 1979 & 17.72 & -230 & -2.06 \\
\hline Grassland & 1340 & 12.00 & 3146 & 28.16 & 1806 & 16.17 \\
\hline Woodland & 1 & 0.01 & 80 & 0.72 & 79 & 0.71 \\
\hline \multirow[t]{2}{*}{ Total } & 11170 & 100 & 11170 & 100 & & \\
\hline & \multicolumn{4}{|c|}{ Land Cover in Did mega } & Land Cove & hange \\
\hline \multirow[t]{2}{*}{ Land Cover Classes } & \multicolumn{2}{|c|}{1985} & \multicolumn{2}{|c|}{2011} & \multicolumn{2}{|c|}{ 1985-2011 } \\
\hline & Area (ha) & $\%$ & Area (ha) & $\%$ & Area (ha) & $\%$ \\
\hline Bare land & 919 & 13.20 & 1069 & 15.35 & 150 & 2.15 \\
\hline Bushland & 4041 & 58.04 & 1860 & 26.71 & -2181 & -31.32 \\
\hline Cultivated land & 851 & 12.22 & 912 & 13.10 & 61 & 0.88 \\
\hline Shrub/grassland with seasonal floods & 339 & 4.87 & 940 & 13.50 & 601 & 8.63 \\
\hline Grassland & 341 & 4.90 & 1908 & 27.40 & 1567 & 22.50 \\
\hline Woodland & 472 & 6.78 & 274 & 3.94 & -198 & -2.84 \\
\hline Total & 6963 & 100 & 6963 & 100 & & \\
\hline
\end{tabular}




\subsubsection{Rainfall Data and the Number of Farmers over Time}

The mean rainfall was obtained by summing the corresponding monthly total rainfall from the decadal rainfall data. To obtain the variation in the rainfall pattern from 1975 to 2012, standard deviations were computed from the mean rainfall. Then, the average rainfall from 1975 to 2012 was computed. Pearson's correlation coefficient test was used to check if there was an association between the deviation of the rainfall from the mean and the number of farmers who started farming within a specific year. The deviation of participants engaged in crop cultivation was not computed because only the number of farmers and the years they started cultivation were recorded and not the total number of farmers in the study areas. Therefore, these indices were tested to check if deviations of the rainfall from the mean influenced the number of farmers starting cultivation in the next year or afterwards.

\section{Results}

\subsection{The Land Cover Changes}

\subsubsection{Land Cover Changes in the Darito Site}

The results of the land cover classification maps generated for the two years in the Darito site are presented in Figure 2a,b and the areas of land cover change between 1985 and 2011 are summarized in Table 2. Between 1985 and 2011 drastic land cover changes occurred in Darito. The percentages of land under cultivation increased greatly and bare land increased slightly. The proportion of areas covered with woodland, grassland, and bushland decreased during the period under study (Table 2). The increase in bare land appeared mostly near cultivated land and, therefore, indicates that these areas used for cultivation over the past two decades are now degraded. Figure $2 \mathrm{~b}$ shows cultivation activities mainly extending eastwards along the seasonal water flow riverine sections of the rangeland (see also Figure 1). The loss of grassland, woodland, and bushland is mainly attributed to increased cultivation activities as illustrated in the 2011 map (Figure 2b). According to our results, rainfall trend of the study area has not significantly influenced land cover changes but could be a necessitating factor that attributed to the increase in cropping activities in the bottomlands wet areas of the rangeland. In particular, in the year 1985, the standard deviation of rainfall in the Darito site was below the overall average and in the year 2011, it was above the average (Figure 7a). The computation of the normalized difference vegetation index (NDVI) shows that while the rainfall was below the average in 1985, the NDVI was higher (0.63 and -0.25), and in the year 2011, rainfall was above the average but the NDVI decreased (to 0.57 and -0.37 ). This implies that there is no correlation between rainfall and vegetation greening. 


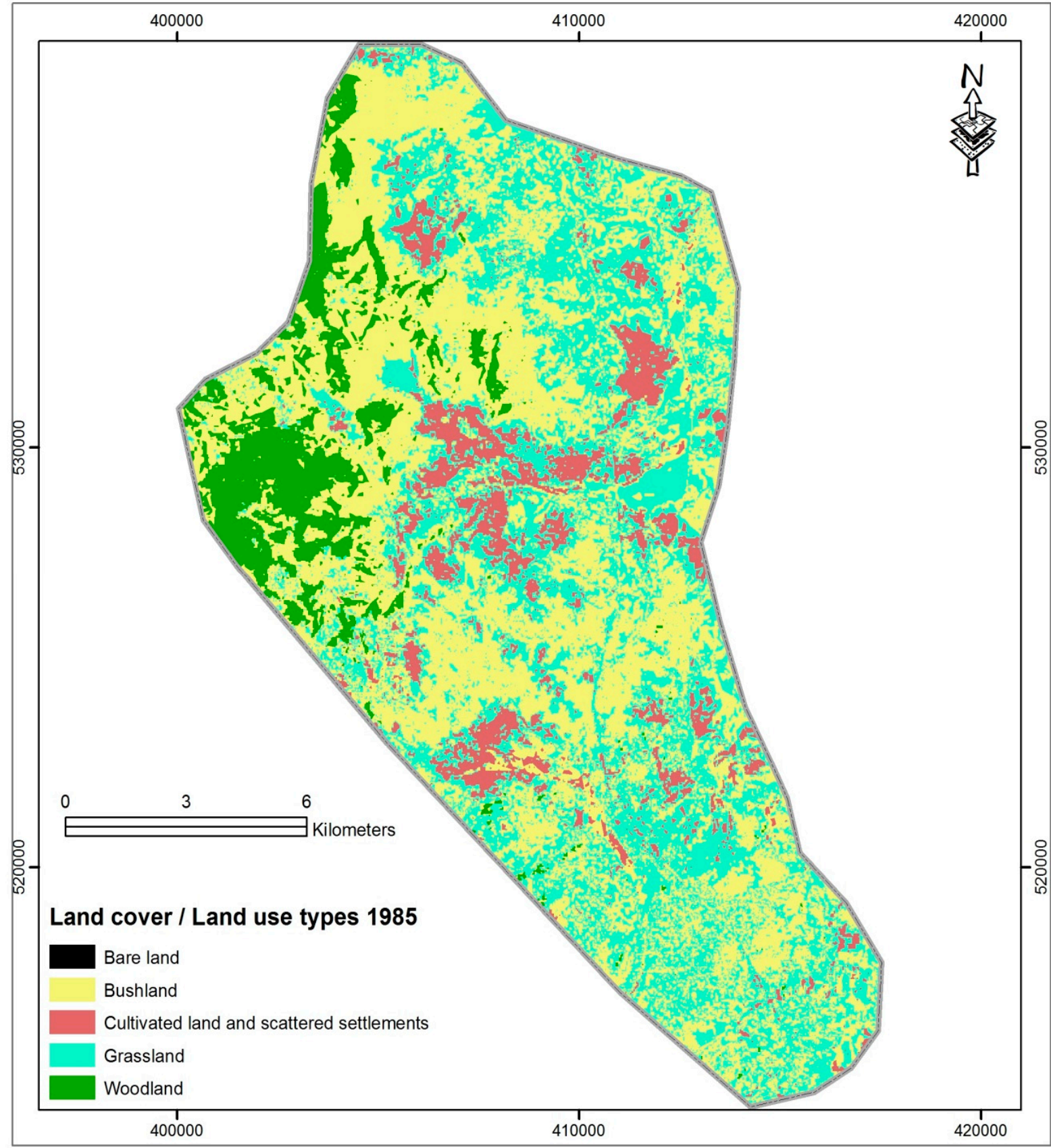

(a) 


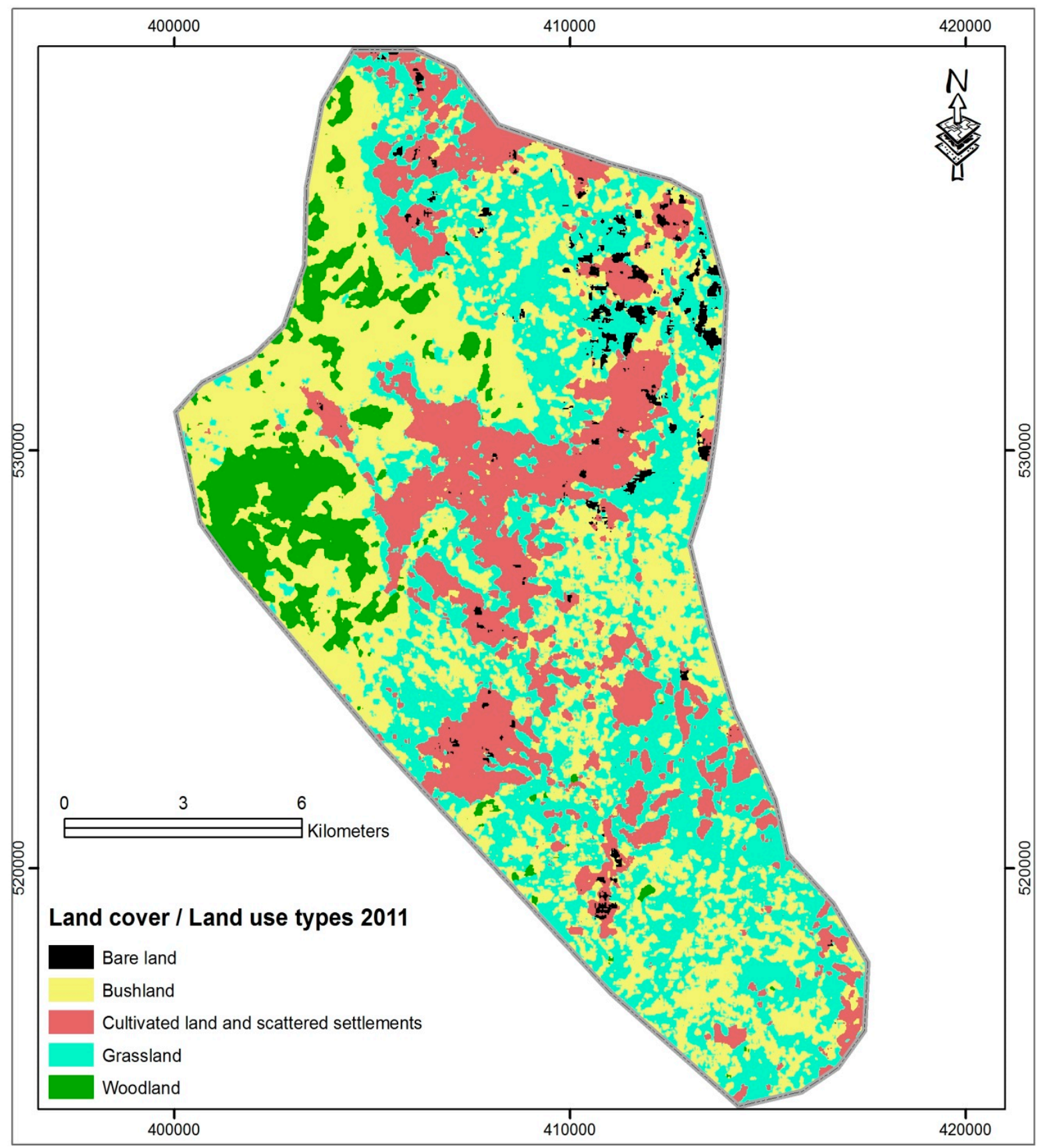

(b)

Figure 2. Land cover classes and land cover changes in Darito between 1985 (a) and 2011 (b).

\subsubsection{Land Cover Changes in Mega Sites}

Figure 3a,b present the land cover maps of the four study sites (Soda, Samaro, Haralo, and Did mega), and Table 3 summarizes the results of the areas of land that changed between 1985 and 2011.

In the Soda site, noticeable changes occurred in land cover types. In the 2011 map, the proportion of the area under shrub/grassland characterized by seasonal floods increased in the lowland areas (Figure 3b). Such increments could be attributed to an increase in water run-off during the rainy seasons. According to our results, there was also an eminent increase of grassland in the 2011 map (Table 3). Other changes occurred in the woodland, which increased in the northwestern part of the 
Soda site in the 2011 map (Figure 3b). Based on the 1985 map, some portions of the rangeland that had been covered by bushland were now dominated by woodland vegetation. There is a great connection between the decrease in bushland vegetation in the site and the increase of grasslands during the study period. The results in (Table 3) demonstrate that the land under cultivation decreased in the 2011 map and adjacent to it, the proportion of bare land areas also decreased. This can be explained by the restoration of grassland and decrease in the proportion of cultivated areas in the southern part of the site in the 2011 map (Figure 3b).

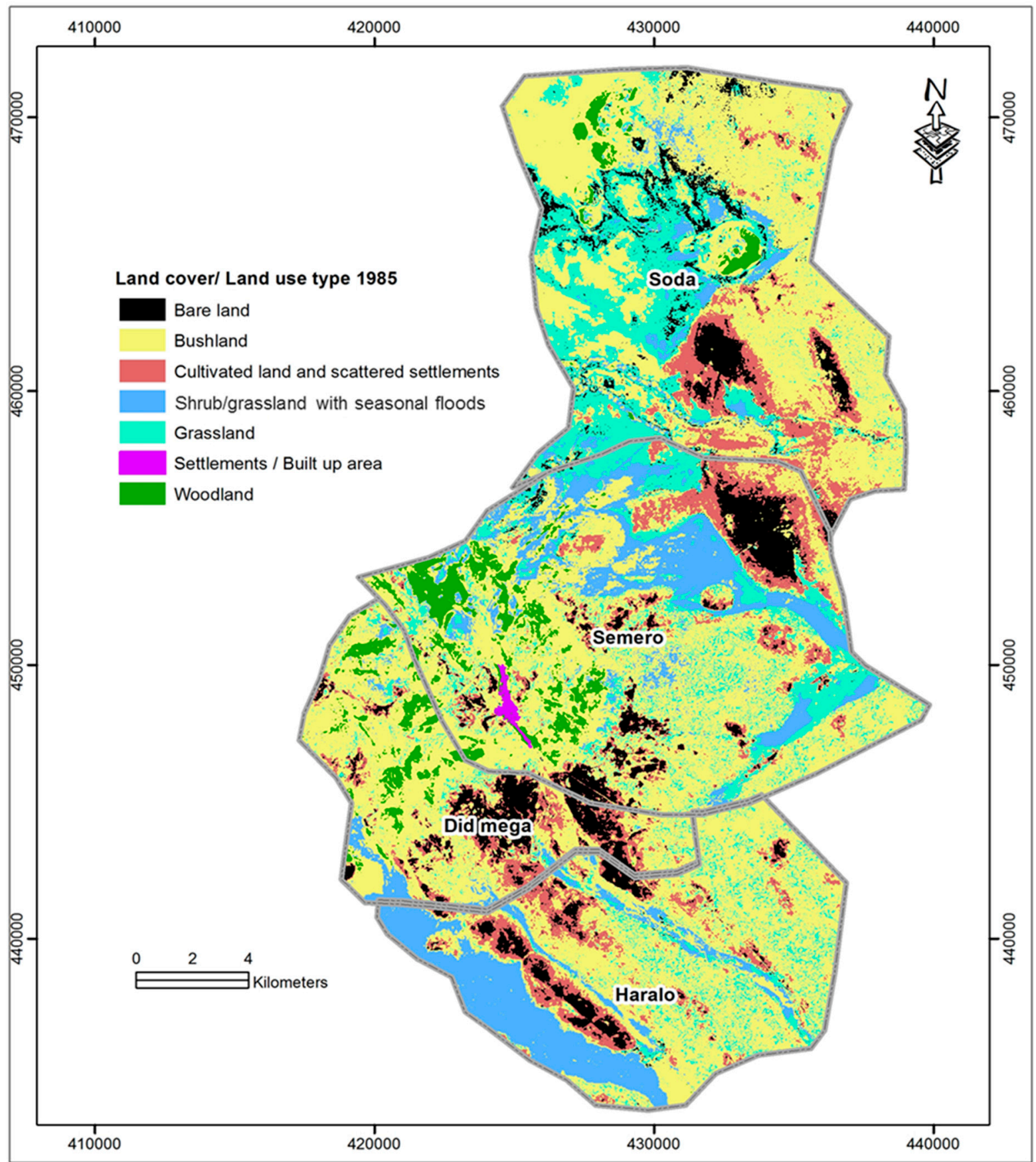

(a) 


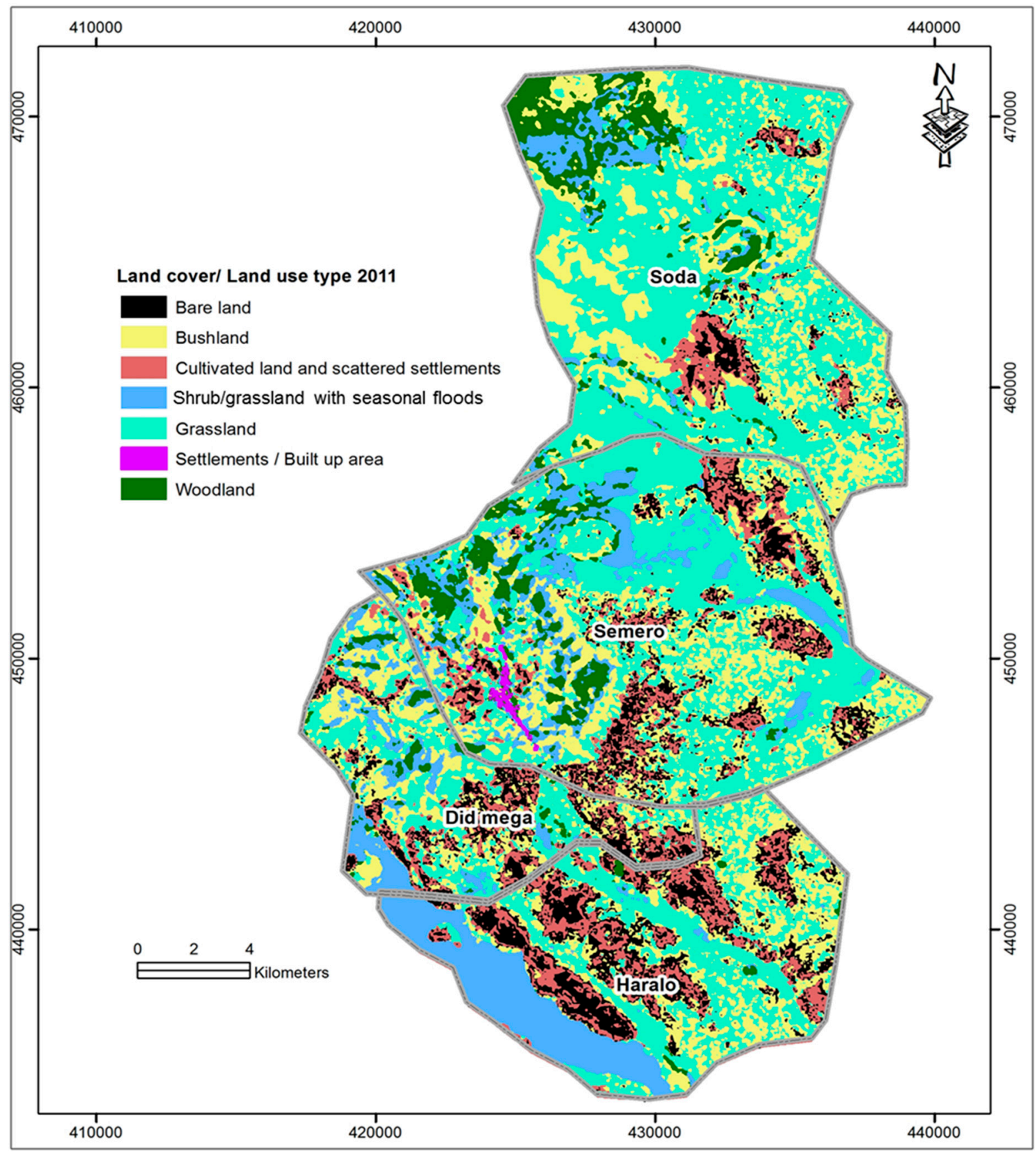

(b)

Figure 3. Land cover classes and land cover changes of four sites in Mega between 1985 (a) and 2011 (b).

Table 3 presents the results of the land cover changes in Samaro where woodland vegetation increased slightly. Additionally, fascinating changes occurred in grassland cover where there was a great increment in the 2011 map, and this is concurrent with an enormous decline in the bushland vegetation (Figure 3b). The decline in bushland can be explained by successful efforts introduced by the district government in the study area to clear bushes, which were overwhelmingly grasslands. Gains of grassland are also concomitant to improved land management such as creation of grassland enclosures and cessation of grazing that allow vegetation to recover. Cultivated land decreased slightly between 1985 and 2011 while bare land increased. In the settlement category, built up areas increased 
to a certain degree, which is attributed to immigration and natural increase. The bottomlands vegetation (shrub/grassland) characterized by occasional flooding decreased slightly in the 2011 map. Variable rainfall in the study area was attributed to land cover changes, in particular to the decline in cultivation activities within the Samaro site. The topographic landscapes around Mega have created an arid condition that limit cropping performance unlike the cases of the Haralo and Did mega sites.

Moreover, in the Haralo site, the proportion of shrub/grassland vegetation in the bottomlands decreased slightly, and this can be explained by the re-growth of vegetation such as grass, herbs or shrubs. As it was detected in the analysis, the grassland cover increased in the 2011 map and this was connected to a decrease of bushland vegetation. Despite the extensive gains in grasslands in some portions of the site, the proportion of bare land in the site increased more than was the case for the rest of the study sites. This is a massive indicator of land degradation obtained in this site (Table 3 ). Woodland vegetation increased slightly during the study period. Nevertheless, the change was very small for this vegetation class.

In the Did mega site, Table 3 shows the greatest increase in the proportion of grassland in the 2011 map (Figure 3b). Explanations for this change are a cessation of grazing, creation of grassland enclosures, and bush clearing practices. Cultivated land on the other hand increased slightly, and there was also an increase in the proportion of bare land during the period under study. The proportion of bottomland vegetation such as shrub/grassland with seasonal floods increased, which is associated to loss of vegetation cover due to expansion of cultivation activities and harvesting of bushes and wood trees for domestic use. Hence the bottomland areas are subjected to seasonal water-logging.

The overall land cover analysis and change detection showed remarkable land cover changes across the study sites. The greatest change is the decrease in the proportion of bush land vegetation in all study areas. Grassland cover also increased significantly in Soda, Samaro, Haralo, and did mega though in the Darito site, the grassland cover decreased. Other changes is the wide spreading of bare land obtained in Haralo and the increase in cultivated areas in the Darito site, which was more extensive than in the rest of the study sites. The rainfall pattern of the study areas fluctuates below and above the overall average, indicating that the areas experienced more droughts than precipitation over the years tested (Figure 7b). The normalized difference vegetation index (NDVI) in 1985 was between 0.57 and -0.12 and in 2011 it was between 0.52 and -0.09 , signifying that vegetation greenness decreased during the study period. However, the decrease in greening of vegetation does not correlate with rainfall trend of the area but with the losses of vegetation cover.

\subsection{Socio-Demographic Characteristics of Respondents}

Of the total 265 respondents involved in this study, 50 were from Darito, 47 from Soda, 57 from Samaro, 50 from Haralo, and 61 from Did mega. Three quarters were males and the remaining 25\% were females. The majority of the respondents were aged 60 years and above (Figure 4). The mean family size for the five study sites was 7.32 at $95 \%$ Confidence Interval (CI), however, there was a difference in mean family size across the study sites (Table 4), and the difference had a significant $(\mathrm{r}=0.53, p<0.0001)$ correlation with the age of the respondents. The level of education attained by the respondents was low, the majority $(n=229)$ had never been to school, only a few $(n=28)$ had 
attained primary education and even fewer $(n=7)$ had attained a secondary education. About 180 of the respondents had at least one schooling child and the other 85 had no schooling child.

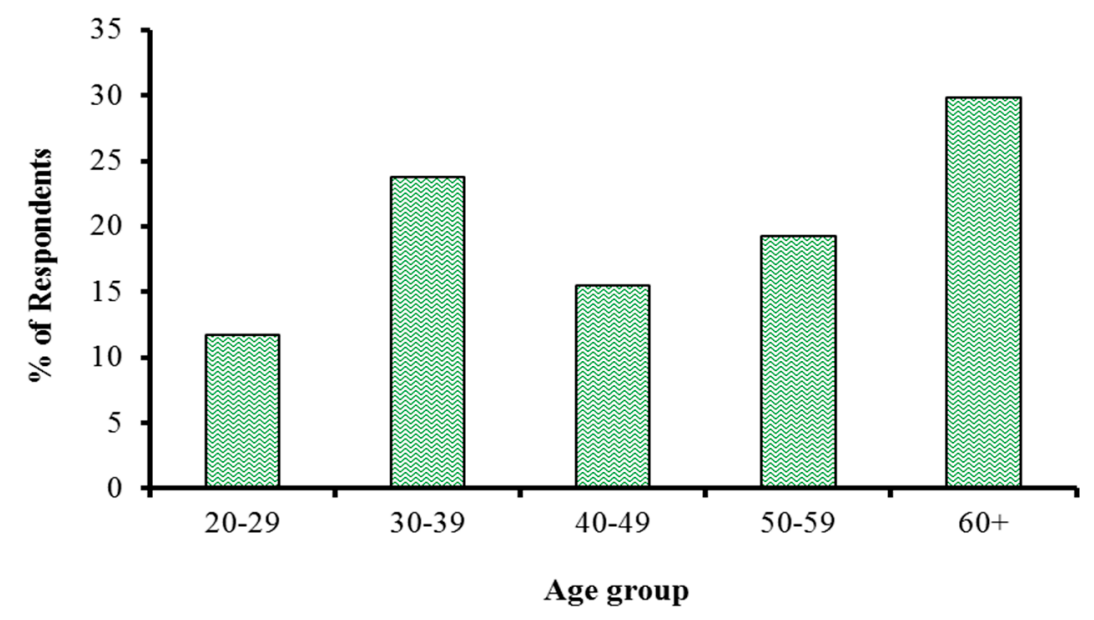

Figure 4. Shows the distribution of respondents by age group.

\subsection{Socio-Demographic and Economic Profiles and Their Linkages to Land Cover Changes}

The majority, 93\%, of the respondents owned land for cultivation, and the average size of farms was 2.10 hectares (ha). The average land size in the Did mega site was higher with 2.79 ha than the overall average size of farms (Table 4). Based on the 173 out of 265 respondents who mentioned their incomes, the mean monthly income varied across the study sites (Table 4). And the variations in income across the study locations are attributed to the size of the family, households with children in school, and the availability of diverse income sources (three or more sources). In particular, the mean income in the Soda site was higher than the overall average income. The main reason is that many families in the Soda site depend more on livestock production because they are a pure pastoralist economy, and the site is endowed with salt extraction activities, which is another injector that contributes to a households' economy. Haralo is the poorest site with the lowest mean income, and the situation is attributed to inadequate livelihood diversification activities.

Table 4. Comparison of mean family size, land size, and income across the study sites (at the time of this research 1 US\$ 17.7 Ethiopia Birr): The mean monthly income is indicated in Ethiopia Birr (ETB).

\begin{tabular}{lcccccc}
\hline Kebele & $\begin{array}{c}\text { Mean Family } \\
\text { Size }\end{array}$ & $\begin{array}{c}\text { Std. } \\
\text { Dev }\end{array}$ & $\begin{array}{c}\text { Mean Farm } \\
\text { Size }\end{array}$ & $\begin{array}{c}\text { Std. } \\
\text { Dev }\end{array}$ & $\begin{array}{c}\text { Mean Monthly } \\
\text { Income }\end{array}$ & $\begin{array}{c}\text { Std. Dev } \\
(\mathbf{l o g})\end{array}$ \\
\hline Darito & 6.88 & 3.589 & 2.00 & 1.161 & 0.00 & 0.00000 \\
Soda & 8.06 & 3.75 & 1.19 & 1.191 & 3424.68 & 1.86032 \\
Samaro & 7.33 & 2.942 & 2.09 & 1.057 & 1456.49 & 0.77329 \\
Haralo & 6.88 & 1.965 & 2.22 & 1.093 & 743.00 & 3.27574 \\
Did mega & 7.44 & 3.384 & 2.79 & 1.368 & 1219.34 & 3.52461 \\
Total & $\mathbf{7 . 3 2}$ & $\mathbf{3 . 1 8 9}$ & $\mathbf{2 . 1 0}$ & $\mathbf{1 . 2 8 1}$ & $\mathbf{1 3 4 1 . 5 5}$ & \\
\hline
\end{tabular}




\subsection{Major Economic Activities and Sources of Income}

Over more than three quarters of the respondents were involved in both crop and livestock farming to earn a living. The rest dealt with only crop farming, only livestock farming, or a combination of crop farming with petty trade or salt extraction. Crop and livestock production accounted for more than three quarters of the income of those interviewed (Table 5). Specifically, the types of crops produced are rain-fed, such as maize, haricot beans, teff, wheat, barley, and sorghum.

Table 5. Ranked economic activities and sources of income of the respondents (from higher to lower).

\begin{tabular}{lcc}
\hline Main Activities & Number & Percentage \\
\hline Crop and livestock farming & 244 & 92.1 \\
Livestock husbandry & 18 & 6.8 \\
Petty trade & 16 & 6.0 \\
Crop production & 4 & 1.5 \\
Wage employment & 4 & 1.5 \\
Salt extraction & 4 & 1.5 \\
\hline Sources of Income & & \\
Livestock husbandry & 255 & 96.2 \\
Crops production & 216 & 81.5 \\
Petty trade & 24 & 9.1 \\
Salt extraction & 9 & 3.4 \\
Wage labour & 7 & 2.6 \\
Brocker & 4 & 1.5 \\
Wage employment & 3 & 1.1 \\
\hline
\end{tabular}

\subsection{Land Ownership and the Temporal Growing of Cultivation Activities in the Study Sites}

According to the results of the focus group discussion interviews with government officials, the right to land ownership is issued by the Ethiopian government and farmers have a user right to acquire land for cultivation. However, despite the existing procedures, some of the policy transformations that took part in 1970s attributed to the changes in land use systems in the pastoral areas of Borana rangeland. Specifically, the key informants explained that traditionally cultivation activities in the rangeland were operated in the sub-humid areas and few ethnic Borana pastoralists were participating. However, the introduction of privatized resources (enclosures) had caused shortages of communal grazing areas and limited animal mobility. In total, the situation affected the socio-economic structure and encouraged pastoralists to diversify their livelihoods with crop production because livestock husbandry had become uncertain. As explained by the participants during group discussions, the intervention of water projects in the 1980s in the Borana rangelands had also caused losses of critical grazing areas. The situation went hand in hand with increasing private enclosures, which altogether affected the livestock sector. The changes in resource use led to a deterioration of livestock production due to shrinking of communal grazing areas, and thus the pastoralists opted to diversify their livelihoods through participation in crop cultivation. The situation changed the land use and management systems in the Borana rangelands and the condition intensified cultivation activities in the bottomlands wet areas of the rangeland. 
Results from survey interviews showed that the temporal increase in the number of agro-pastoralists was higher in the Darito and Did mega sites while in the Soda site, the number of agro-pastoralists started to increase from 2000 to 2012. In the case of the Samaro site, there was a slight decline during the same period (Figure 5). The decline in the number of agro-pastoralists in Samaro can be explained by the arid climate that constrained the crop performance. As mentioned by the agro-pastoralists, other reasons attributed to the dynamics of the number of agro-pastoralist across the study sites are the availability of man-power, ability of individuals to purchase a piece of land from relatives, requesting land from Kebele administration, renting land or share-cropping arrangements. In the case of some of the agro-pastoralists interviewed, they could not recall how they had acquired their land. Informal conversion of the rangeland into agricultural land is another factor that contributed to the increased cultivation and the deviation in the number of agro-pastoralists across the study sites.

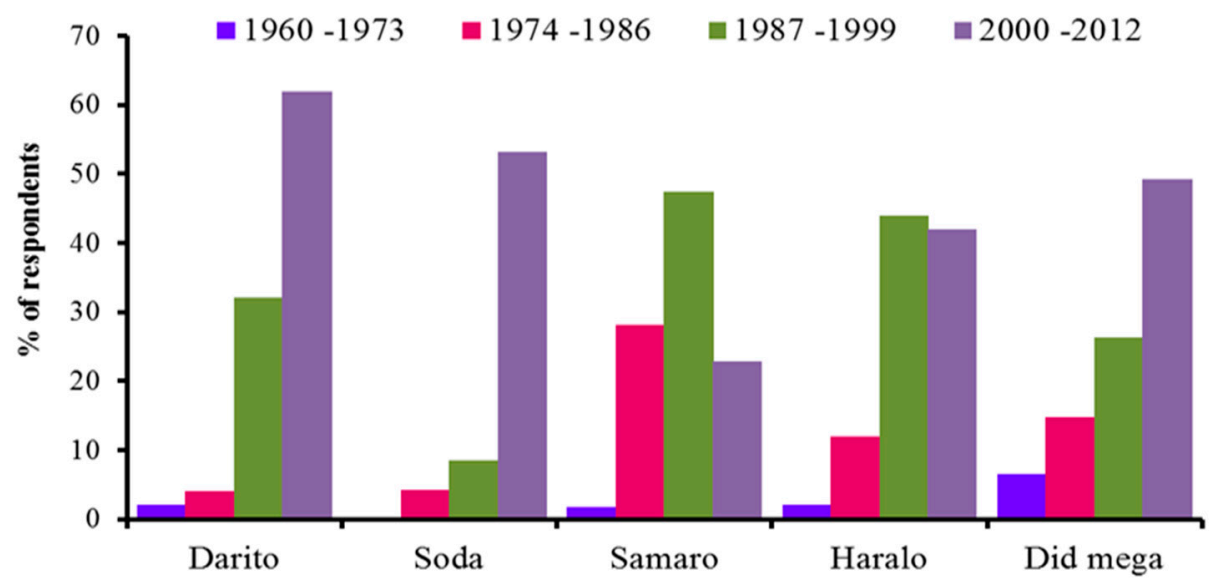

Figure 5. Comparison of temporal trends: increasing numbers of agro-pastoralists from 1960 to 2012 in Kebele.

The results further show that, of those who owned land, 158 of the cultivators had plot sizes between 1 and 2 hectares (ha) and 88 cultivators had land sizes of more than 3 ha. The proportion of people who had no land was significantly higher in Soda, and those with 1-2 ha was higher in Samaro and those who owned more than 2 ha was higher in Did mega (Table 6). The reasons for the observed differences are three-fold. First, larger family size was significantly correlated with the size of land owned by a household. Second, many families with $>2$ ha of land were those with children in school, and this is linked to early sedentarization whereby families living closer to Mega town are more likely to have been sedentary for longer, meaning that they had the opportunity to acquire more land. Families who were more mobile had a lesser chance of sending their children to school and acquiring land. Third, households, which started cultivation from 1980-1999, had bigger plots of land than those that started in from 1960-1979. The reason for this is that in the 1960s and 1970s, cultivation activities in the Borana rangeland were minimally practiced and the economies of many households relied more on livestock husbandry. During group discussion interviews, participants specified that the few families who had been engaged in crop farming in 1997 had such good yields, especially after El Niño rains, that other pastoralists became motivated to start their own cultivation. On the contrary, the statistical analysis of the decadal rainfall pattern across the study sites is not comparable with the effects of El Niño rains on land cover changes. More verification is needed with regard to this. 
Table 6. Comparison of land size distribution (measured in hectares (ha)) in various sites across the Kebele, by family size, children in school, and cropping history ( $X^{2}$ test).

\begin{tabular}{lcccc}
\hline Kebele & $\begin{array}{c}\text { O ha } \\
\text { Numbers }\end{array}$ & $\begin{array}{c}\mathbf{1 - 2} \text { ha } \\
\text { Numbers }\end{array}$ & $\begin{array}{c}>\mathbf{2} \text { ha } \\
\text { Numbers }\end{array}$ & p-Value \\
\hline Darito & 0 & 35 & 15 & \\
Soda & 17 & 22 & 8 & \\
Samaro & 0 & 42 & 15 & $<0.0001$ \\
Haralo & 0 & 34 & 16 & \\
Did mega & 2 & 25 & 34 & \\
\hline Family size & & & & \\
$<5$ & 3 & 37 & 9 & \\
$5-10$ & 8 & 111 & 62 & 0.0001 \\
$>10$ & 8 & 10 & 17 & \\
\hline School going child & & & & \\
Household with schooling child & 16 & 95 & 69 & \multirow{2}{*}{0.0038} \\
Household with no schooling child & 3 & 63 & 19 & \\
\hline Cropping history & & & & \\
1960-1979 & 0 & 10 & 9 & \\
1980-1999 & 0 & 59 & 49 & 0.01538361 \\
2000-2012 & 1 & 89 & 30 & \\
\hline
\end{tabular}

\subsection{Perceived Drivers behind the Expansion of Cultivation}

According to the survey interviews, the agro-pastoralists explained that the expansion of cultivation in the rangeland was attributed to climatic and socio-economic constraints. Figure 6, presents the perceived drivers behind the expansion of cultivation in the study sites. The drivers considered were: recurrent drought, food insecurity, income diversification, and a decrease of pasture. Recurrent drought, food insecurity, and diminishing pasture were considered to be the main reasons attributed to the expansion of crop cultivation in Darito. In Soda, Samaro, Haralo, and Did mega, food insecurity, a desire to diversify income and recurrent drought were the major reasons. As specified by the respondents, recurrent drought had caused diminishing grazing pasture, a decline in livestock holdings, and a state of food insecurity, all leading to an overall decline in household income. Therefore, in order to obtain food and income security the pastoralists are engaged in cultivation activities in the relatively wet areas of the rangelands.

Specifically, variable rainfall is a key environmental constraint affecting the pastoral production system. The key informants specified that over the past 15 years recurrent drought had caused deterioration of pasture and consequently led to severe livestock mortality. During group discussions, the pastoralists stated that many households lost their herds through the succession of extreme droughts between 1983 and 1985 and during the 1990s, when there was starvation. The livestock mortality caused famine and a decline in per capita household income. Thus, for pastoralists in this region to improve their wealth, they had to introduce cultivation activities to diversify their livelihoods. Despite the unreliability of rainfall, rain-fed crops such as haricot beans, sorghum, maize, teff, and barley, could be produced in the agro-pastoral areas under specific rainfall conditions in the sub-humid areas and to the lowland wet areas of the rangeland. 


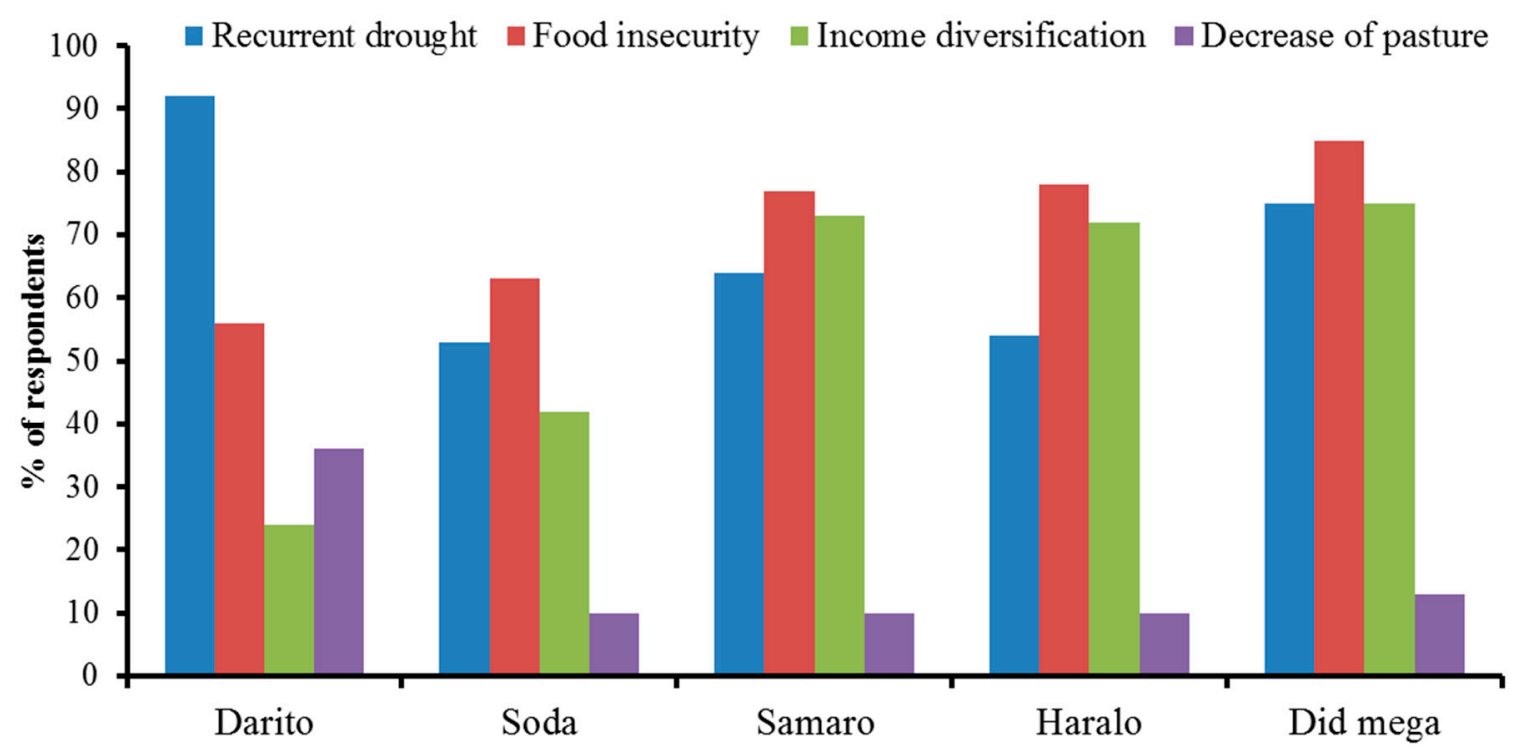

Figure 6. Drivers behind the expansion of cultivation in the study sites.

\subsection{Decadal Rainfall and the Number of Farmers Who Started Cultivation over Time}

Results show that the rainfall trend in Darito site deviates greatly from the long-term mean with marked increases and decreases over time (Figure 7a). Between 1980 and 1985, recurrent drought rather than precipitation dominated the area, and rainfall was below the mean. The comparison between the deviations of the rainfall and the number of farmers who started cultivation indicates that there is not a statistically significant relationship $(p>0.388)$. Nevertheless, there is a general tendency that, in some drought years, the number of famers did not show any sign of decline and even in the year after rainfall the number of farmers did not suddenly increase. Although the sampled farmers indicated the exact year they began to cultivate in relation to rainfall pattern, the increasing variability and unpredictability of rainfall in some ways have triggered the pastoralists in this region to diversify their livelihoods through crop cultivation.

Similarly, Figure $7 \mathrm{~b}$ demonstrates rainfall trends in Soda, Samaro, Haralo, and in Did mega. The area also experienced marked rainfall fluctuations from the long term mean. The correlation analysis between rainfall and the number of farmers also shows that there is not a statistically significant relationship $(p>0.521)$. This is evidenced by an increase in the number of farmers even in the driest years. Although the agro-pastoralists and the key informants explained that recurrent droughts intensified the increase in cultivation activities, this analysis cannot conclude that rainfall trends of the study locations are the sole factor for studying the factors attributed to the expansion of cultivation because the two indices (rainfall vs. number of farmers) are not correlated. 


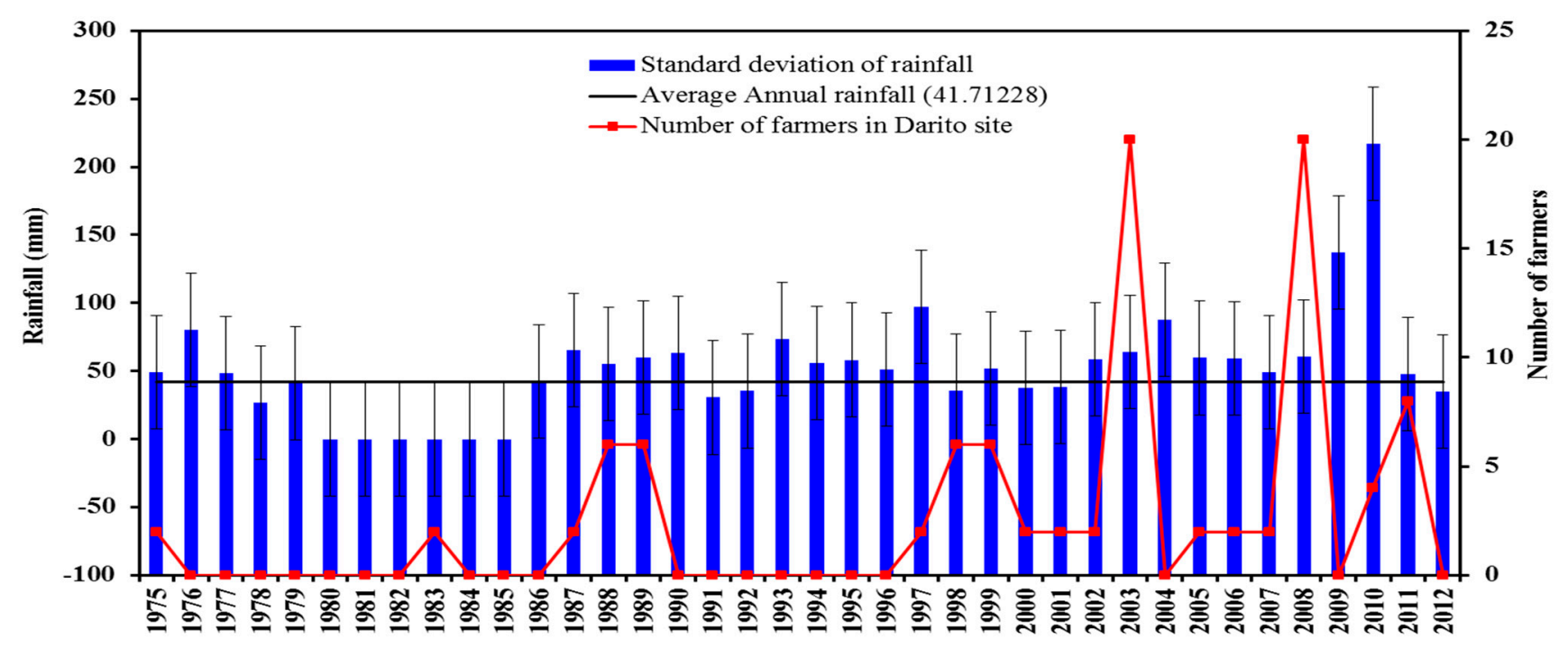

(a)

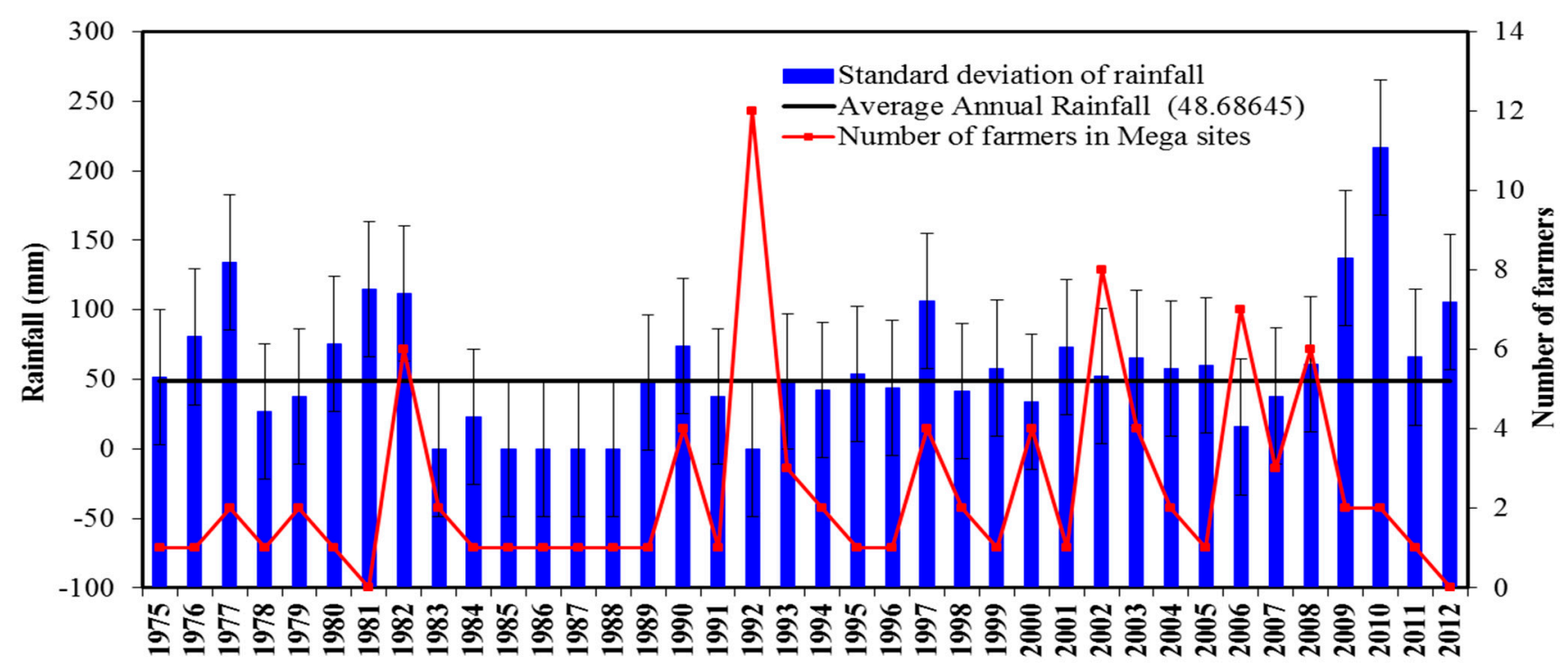

(b)

Figure 7. (a) Comparison of the deviation of rainfall from the long-term mean and the number of those engaging in crop farming in Darito: Source: Ethiopian Meteorological Agency 2012; (b) Comparison of the deviation of rainfall from the long-term mean and the number of farmers in the Mega sites: Source: Ethiopian Meteorological Agency 2012.

\subsection{The Implications of Cultivation Practices and Land Management on the Rangeland}

Prior to cultivation, the farmers across the study sites use the major four farming practices to prepare their fields (Figure 8). Slash and burn is used more in Samaro, Haralo and Did mega, and to a small extent in Darito. Burning of crop residuals during the preparation of fields is practiced highly in Did mega and Darito, and only few farmers sowed without clearing. The techniques used to prepare land for cultivation in these study sites have major concerns regarding the rangeland. Slush and burn deteriorates vegetation biomass and reduces soil organic carbon while ploughing contributes to the 
emissions of greenhouse gas, soil erosions, and land degradation. The practices reduce the capacity of carbon storage and sequestration benefits in the rangelands.

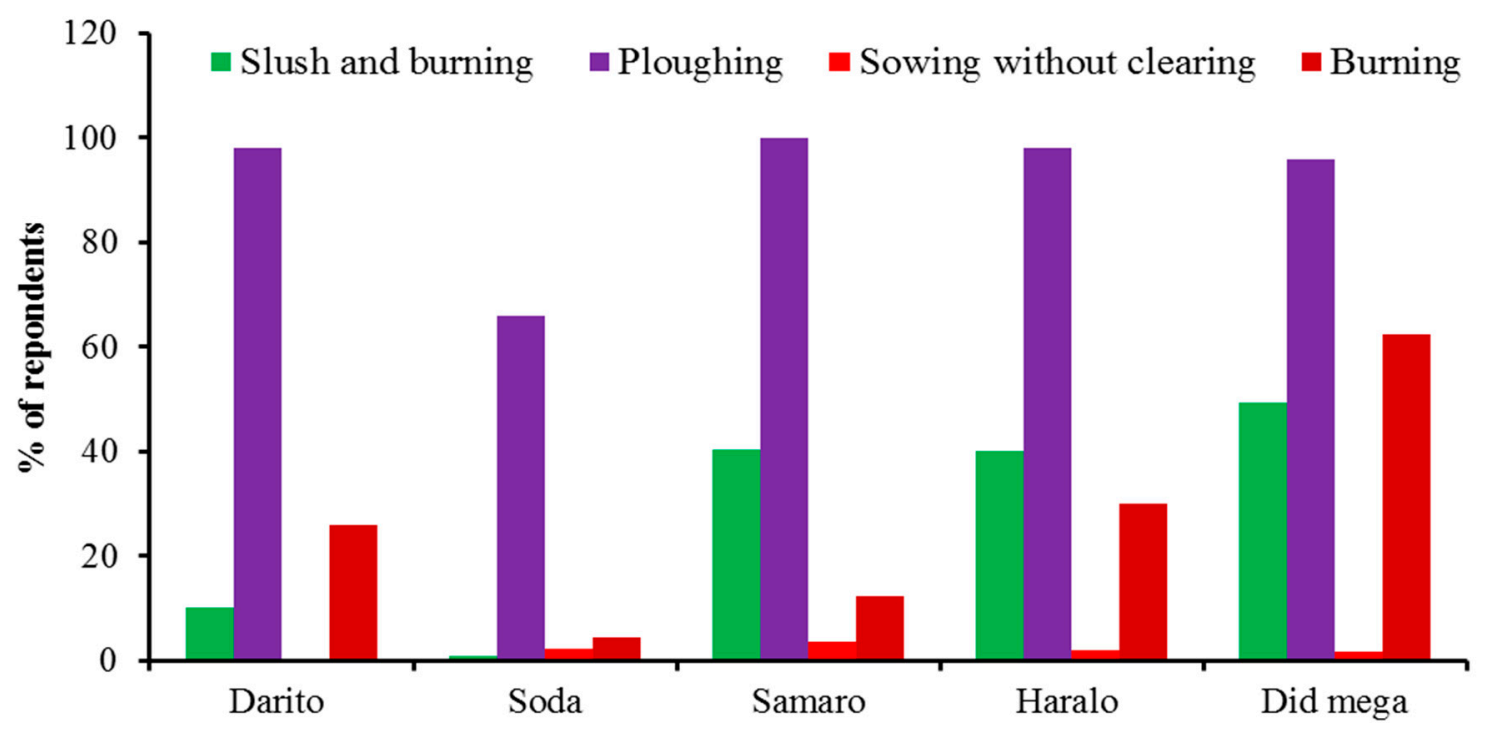

Figure 8. Land preparation under crop cultivation.

Concerning management practices, there are differences across the study locations. The agro-pastoralists in Haralo and Did mega sites are engaged in conservation practices such as use of compost, soil water conservation, terracing, seedling nursery, and water harvesting. In case of other agro-pastoralists communities in Darito, Soda, and in Samaro, there are little efforts invested in conservation farming (Figure 9). The implications of this are deterioration and fragmentation of the rangeland.

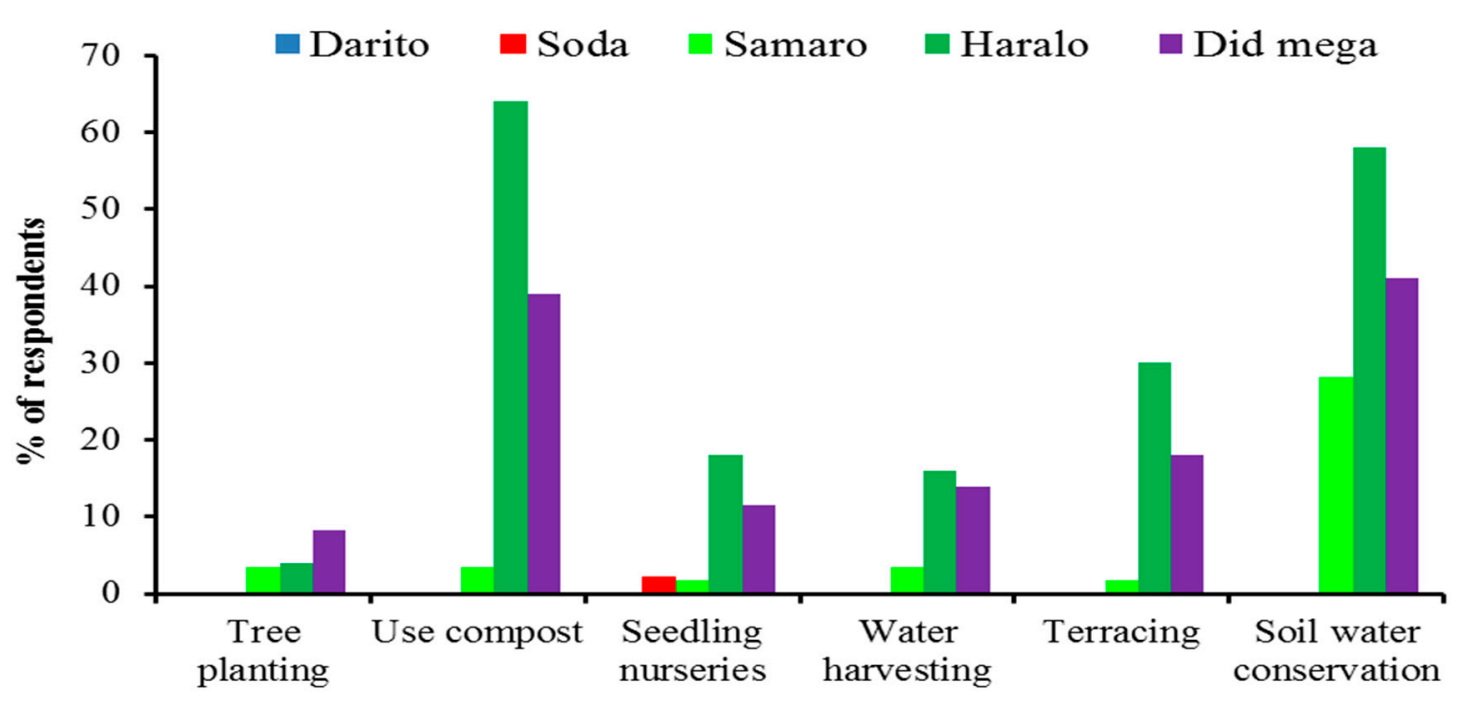

Figure 9. Farming management practices. 


\section{Discussion}

\subsection{Land Cover Changes between 1985 and 2011}

The land cover changes between 1985 and 2011 were analyzed in the five study sites, namely Darito, Soda, Samaro, Haralo, and Did mega. The analyzed remotely sensed data detected considerable changes across the study areas. Specifically, grassland and bushland vegetation in the central and northeastern part of Darito had decreased, and this was connected with increases of cultivation as seen in the 2011 map. The central and eastern portions of the rangeland in Darito are the areas subjected to land conversion for cultivation because they are characterized by wet soils along the bottomlands where seasonal water-logging occurs (Figure 2b, see also Figure 1). The loss of woodland vegetation along the hill escarpments of Darito has also been attributed to the expansion of crop cultivation as revealed in the 2011 map. The present findings are supported by [32] who found that the percentage of cultivated land increased in the Yabelo district of the Borana rangeland between 1960 and 2000 and caused a serious loss of natural vegetation in the rangeland. A similar loss of woodland vegetation in the Did mega site is also due to the expansion of cultivation activities (Table 3). The implications of increasing cultivated areas in the rangeland are loss of grassland and bushland as detected in this study. This is a main concern regarding livestock and pasture because the bottomland grasslands are dry season grazing reserves and, therefore, converting them into croplands adversely affects critical grazing resources. The ecological implications of inappropriate farming techniques are the losses of vegetation biomass (grassland, bushland, and woodlands) and below ground carbon stocks, consequent, reduce the capacity of the rangeland ecosystems to store and to sequester carbon.

Apart from cultivation pressure, participants during group discussions explained that harvesting of bushes and wood trees for charcoal, fuel-wood, fencing, and construction purposes are other possible causes of vegetation fragmentation in the rangeland. The key informants such as the development agency officials in the Kebele clarified that expansion of cultivation and clearing of wood trees have led to increased loss of natural vegetation in the rangeland. The loss of vegetation such as bushes and wood trees will constrain the supply of fuelwood, fodder, non-timber forest product, and building materials available to the inhabitants. As it is, the proportion of woodland vegetation in the rangeland is very low. The loss of woodland vegetation in other African drylands is a common environmental problem, and it is mainly attributed to the expansion of cultivation [33] and clearing of trees for charcoal and fuel-wood, in particular the northern rangelands of Ethiopia [34]. Other changes are shown by the gains of woodland vegetation in the northwestern part of Soda, western Samaro and in Haralo (Figure 3b), and such gains were possible in the mountainous escarpment because human interactions are limited. Specifically, within the Soda site, the areas that were dominated by bush vegetation in the 1985 map are now replaced by wood vegetation. This is a positive change for ecosystem integrity because woodland biomes have a high potential for above ground biomass storage hence carbon sequestration benefits. In the Haralo site woodland vegetation has increased to some extent and a wide proportion of the area is bare land.

The percentage of bare land increased significantly (Table 3), and this is attributed to the expansion of cultivated areas and loss of vegetation cover. The increase in bare land is also linked to past land use and management practices related to grazing [15]. A recent study showed that bare land areas extended 
adjacent to cultivated land (Figures $2 \mathrm{~b}$ and $3 \mathrm{~b}$ ), and the trend indicates that inappropriate farming techniques attribute to soil erosion and land degradation. During transect walks with farmers, some portions of the rangeland had already been degraded and a large gully erosion had advanced. The expansion of bare land exposes soil to erosion, leading to loss of nutrients and soil organic carbon $[35,36]$. Consequently, the process alters soil carbon storage and sequestration benefits in the rangelands [37]. The increase in bare land due to cultivation pressure in other rangelands of Africa have also been reported [38,39] and the authors advocated that inappropriate land management poses a serious concern to ecosystem integrity and people's livelihoods. Exceptional change occurred in the Soda site whereby the percentage of bare land decreased in the 2011 map, and such changes were attributed to the regeneration of grasslands and reduction in the area under cultivation.

Moreover, there is a significant increase in the proportion of grassland in Soda, Samaro, Haralo, and Did mega in the 2011 map (Table 3). The recovery of grassland is attributed to the past interventions of the Southern Rangeland Development Unit (SORDU) project [15]. The establishment of grassland enclosures and grazing cessation has contributed to the progressive recovering of grasslands. Extensive portions of the rangeland, which were dominated by bush vegetation in the 1985 map, have been colonized by grasslands in the 2011 map. Previous studies [16,19,20] showed that bush encroachment had altered the availability of palatable grassland pasture and animal mobility. However, concurrent efforts made by the district government to clear bush trees have contributed to an increase of grasslands and a decrease in the proportion of bush vegetation. Current evidence suggests that the changes obtained in the grassland are associated with the implementation of the land rehabilitation program, in particular bush clearing, cessation of grazing, and creation of grassland enclosures. This is a successful story in the grasslands but diminishing bushland vegetation has negative effects such as risk of fire and loss of above ground vegetation biomass. The decrease of bushland put serious constraints on browser animals, such as goats, sheep, and other game animals, because they feed on bushes. Apart from the deterioration of fodder, loss of bushland vegetation limits access to fuel-wood, fencing and building materials, and inhibits harvesting of non-timber forest products, such as those with medicinal values. In terms of ecosystem services, a loss in bushland reduces the proportion of above ground vegetation biomass and carbon storage capacity. Other negative consequences could be soil erosion and possibly losses of soil organic carbon. Furthermore, a variable rainfall pattern is a major agro-climatic constraint that supports or limits cropping performance. Specifically, the inhabitants of the Soda site only practice pure pastoralists and crop cultivation to a limited extent. The comparison of the results of the change detection with the land ownership in the Soda site indicated that the site had the highest numbers of people without land from the 1960s to 1999, which differed from other Kebele (Table 6, see also Figure 5). Afterward, the number of agro-pastoralists started to increase from 2000 to 2012, and the change was attributed to the increase of socio-environmental constraints, in particular, aridity conditions of the area affected by topographical landscape. Nevertheless, the observed trend in the increase of the number of agro-pastoralists in the Soda site is not comparable to the land cover change. The analysis managed to capture observable land cover changes, but the numbers of agro-pastoralists sampled during the survey interviews were consisted of those farmers who started cultivation around the year 2000 and afterwards. Given the uncertainty of livestock production, diversification of livelihood with crop production in the study site is inevitable. In the Samaro site, the area is affected by the topography and it is characterized more by an arid 
climate than by precipitation. Such a climatic condition restricts cropping activities compared to other sites such as Haralo and Did mega, which are located on the lowland plain of Mega. A topographical difference, as clarified by [40] is one of the key factors that influences the microclimate in Ethiopia. Other factors that might have contributed to the decrease in cultivated areas in Samaro could be soil characteristics, which differ across the four study sites. The comparison of the results of land cover change and cropping trends (Figure 5) demonstrate a corresponding association whereby the number of agro-pastoralists started to decline from 2000 to 2012.

Built up areas also increased in Samaro Kebele (Table 3), and this can be explained by the growth of Mega town due to the influx of immigration and natural increase. In the last category, the proportion of shrub/grassland vegetation decreased slightly, and those areas which were characterized by seasonal water-logging were subsequently colonized by grass, dwarf bushes or herbs. However, in some bottomlands of the Soda and Did mega sites, shrub/grassland vegetation increased. This is attributed to the accumulation of water-logging during rainy seasons. The intensity of water flowing to the bottomlands of Did mega is attributed to the spread of bare land and loss of vegetation cover. Inadequate construction of water breakers during rainy seasons has also contributed to increase of water-logging in the bottomlands.

The implications of cultivation in the rangeland were analyzed by evaluating the practices used by farmers to prepare and manage their land. Just like in many other African countries, slash and burn is a widely used practice for the preparation of fields in the study sites (Figure 8). Continuous ploughing without fallow periods reduces the soil's ability to produce humus and soil fertility. The consequences of this practice are loss of habitat and species, an increase in air pollution, and the release of carbon into the atmosphere [39]. Soil erosion is one of the significant consequences of this practice in the study areas, and the intensity of erosions increased in the lowland areas. Figure 10 illustrates the effects of cultivation on the development of gully erosions in the Did mega site. This is attributed to inadequate adoption of recommended farming techniques such as construction of water breakers, terracing, and the planting of trees (Figure 9). The results provide the insight that unsustainable farming practice is not a better way of using rangelands. It is, therefore, necessary to improve farming practices in order to minimize the loss of soil organic carbon and vegetation biomass.

From the above analysis, the changes (positive and negative) in land cover obtained here varied across the study locations. The greatest change is found as a large increase in the proportion of bare land in Haralo. The decrease in the proportion of bushland vegetation occurred in all five sites, and extensive increase in cultivated areas occurred in Darito to a greater proportion than in the rest of the sites. The results from this study establish a strong indication that increasing human pressure on land uses and the expansion of cultivation activities in the study sites have attributed to loss of vegetation biomass, soil erosion, and land degradation. 


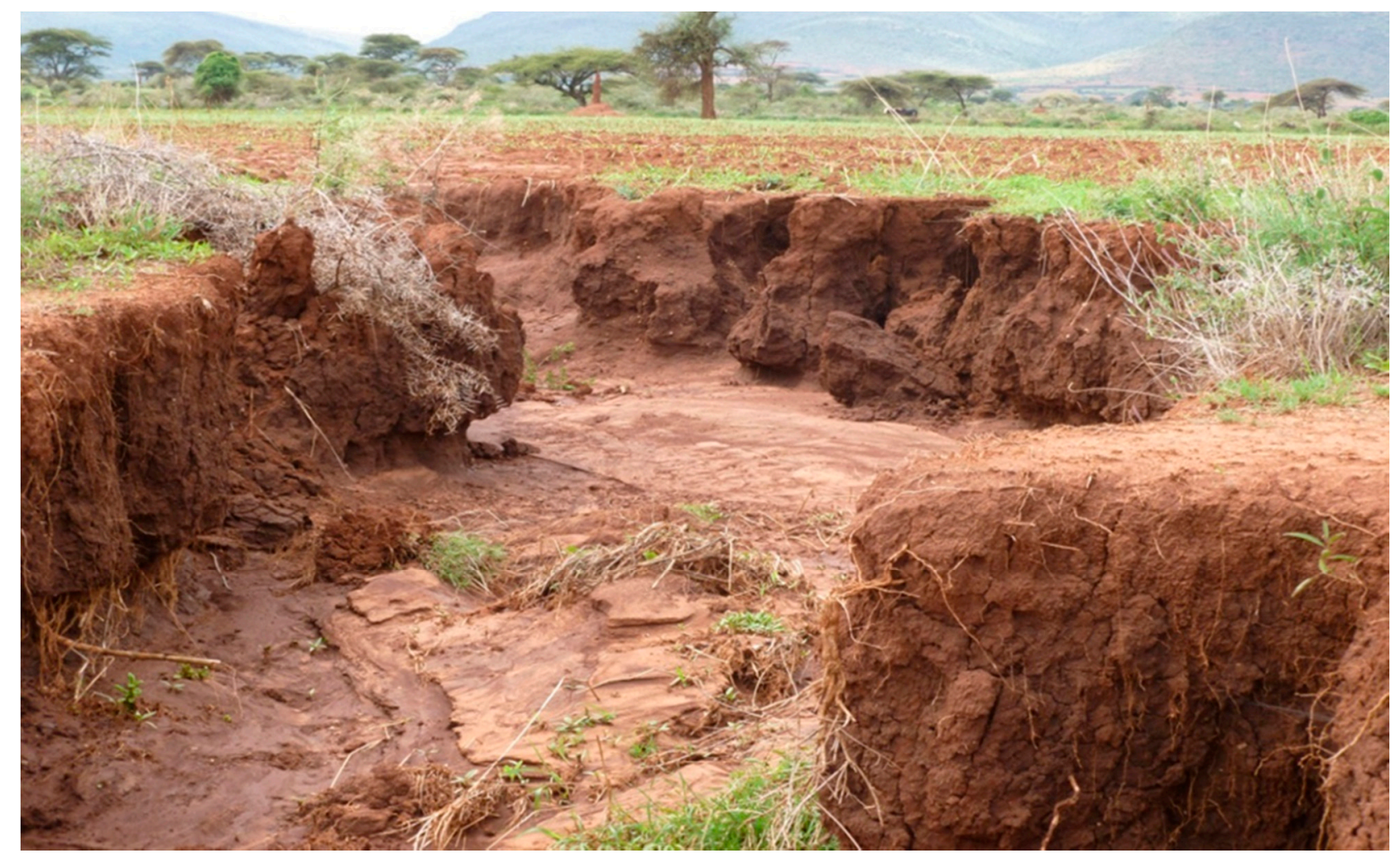

Figure 10. Development of gully erosions around cultivated land in the Did mega site (photo November 2012).

\subsection{Drivers Contributing to the Expansion of Cultivation in the Rangeland}

The analyses have shown that the expansion of cultivation in the studied sites is attributed to environmental constrains, socio-economic, and demographic factors. Demographic variables such as family size played a critical role in the study areas. The major role is the provision of a labor force for different livelihood activities both on and off farms. It appears that most families with more members in their households owned larger plots of land for cultivation. This is evidenced by the significant difference between family size and land size (Table 6). According to [41], the immediate factor influencing land use decisions at local level is the household. This appears to correlate with the situation in this study where the agro-pastoralists from the entire studied site are engaged in cultivation because they need to create additional income to support their families. The availability of a labor force in a household has also necessitated the expansion of cultivation in the studied sites. The association between the expansion of agricultural land in the semi-arid lands of Yatta sub-county and demographic variables such as population, has also been elaborated by [21], and the authors found a significant association between the indices. Cultivation in the study sites is considered to be a major livelihood diversification option because incomes derived from selling grains help families to afford education costs of their children. In our results (Table 6), most families with children in school depend more on crop production because it is a source of income. The experience across the study locations shows that it is rare to find families with school-going children that are do not participate in cultivation activities. The situation has led to an increase in the demand of land for cultivation across the study locations. 
The agro-pastoralists interviewed specified that food insecurity was another factor contributing to the expansion of cultivation. Most agro-pastoralists in the study locations have been in an extremely vulnerable state of food shortage due to recurrent drought. As explained by the participants during group discussions, cultivation in the study locations began as far back as the 1960s, but few people were engaged. It was intensified by the worst drought incidents in 1984, 1985, 1992, and 2000 that caused severe livestock mortality and decline in household herds. According to [42], the occurrence of drought leads the pastoral communities to be faced with food insecurity due to livestock mortality. Recurrent drought episodes are increasingly worsening livestock production; the majority of the pastoralists are embracing crop production in order to cushion themselves against food shocks. The pastoralists, therefore, have increasingly engaged in crop cultivation in the relatively wet sections of the rangelands (lowland plain areas) and in the sub-humid areas. Recurrent drought as a reason behind the expansion of cultivation across the study sites is similar to [24] who reports other incidences of droughts in 1991 and 1992 and by [43] who describes other drought incidences in the 1970s. According to the authors, variable rainfall and deterioration of livestock production have caused food shortages in the Borana rangeland, and thus in order to secure food grains, pastoralists have started crop production in the good years with rainfall. The authors noted a decline in the percentage of pure pastoralists from $15 \%$, to $8 \%$. Such a decline is also consistent with [19] who found that $92 \%$ of the inhabitants of five peasant associations in the Borana rangeland were agro-pastoralists who relied on both livestock and crop production. The increase in agro-pastoralists in the present study is also explained by a progressive increase in households practicing cultivation from 1960 to 2012 in the Darito, Soda, and Did mega sites except for a slight decline that was obtained in the Samaro site from 2000 to 2012 (Figure 5). The proportion of agro-pastoralists is evident with the increase in the number of households engaged in crop cultivation from $35 \%$ reported by [15] to $87 \%$ reported by [43]. The $92 \%$ figure obtained in the present study is also consistent with the figures obtained by $[19,20]$ in their studies.

The need to diversify income at household level is another factor that contributed to the expansion of cultivation in the study sites. The mean household income obtained in this study varied across the study sites (Table 4), nevertheless, reported amounts were insufficient to support households' basic needs. According to the agro-pastoralists, they claimed that their incomes had been declining due to unreliable livestock production. Although the initial income before the occurrence of droughts was not captured in this study, the mean incomes revealed across the study sites provide significant insight into the economic situation of the agro-pastoralists and its implications on the expansion of cultivation activities. Experiences from other pastoral areas of eastern African rangelands show that diversification of income through crop production is the key livelihood option [44]. Income generated from crop production helps the pastoralists to buy food, support their families, and reconstruct their economies. Specifically, the money generated from selling food grains is used to pay school fees, pay for health services, begin petty business, and purchase livestock for post-drought recovery. A similar situation is reported by [19], i.e., that the Borana agro-pastoralists are increasingly engaging in crop cultivation to rebuild their wealth. The majority of the pastoral households in the study sites are increasingly embracing crop production in response to the past devastating droughts that affected their livestock. 
Another underlying driver behind the expansion of cultivation as mentioned by the key informants and also during group discussions is the increase of local and cross-border immigration that has led to the development of towns like Mega and Yabelo. The growth of towns has contributed to population growth and hence has led to a higher demand of land for cultivation. However, due to inadequate census data of population trends across the studied sites, it was not possible to cross-reference this assertion. Further investigation into this is recommended. Further evidence of population growth and land conversion in Eastern Africa rangelands have been described by [45] for the case of Kajiado rangeland of Kenya and by [20] for the Maasai pastoral areas. According to the authors, the Maasai pastoralists from Tanzania have embraced crop cultivation to complement livestock production, which seems to be deteriorating over time.

Moreover, verification of the impacts of recurrent drought and the expansion of cultivation activities were analyzed by testing the correlation between rainfall and the number of famers who started cultivation. Although the rainfall pattern in the study areas fluctuates greatly, there is no clear statistical mark to validate the influence of rainfall trend on dictating the farmers' engagement in cultivation activities. The deviation in the rainfall and the fluctuation in the number of farmers are not statistically significantly correlated. The results are supported by [46] who found that the rainfall trend in Southern Ethiopia did not show a significant decline but that the area was characterized by long-term fluctuations. It should be noted that the rainfall pattern of the study sites fluctuates below and above the average in some years. It is, therefore, possible that such fluctuation trends and recurrent droughts, as mentioned by the farmers and demonstrated in Figure 7 ( $a$ and b), could be the underlying basis for justifying the expansion of cultivation in wet areas of the rangeland and, on the other hand, it contributes to the decline in cultivation activities in other sites. According to [15], 12\% of the wet areas of the Borana rangelands can support rain-fed crop production (teff, sorghum, barley, and haricot beans); this makes the expansion of cultivation across the study sites possible.

Furthermore, according to the Ethiopian government land policy, land resource is communal, and it is the property of the federal government. When the key informants were asked about the land tenure system in Ethiopia, they pointed out that access to land could only be acquired through leasing, and this is regulated by the Ethiopian government. According to the federal government of Ethiopia, it issues "use rights" to the farmers to own land for the purpose of farming and prohibits them from selling land [47]. Despite the existing regal procedures, informally, another possibility used by the agro-pastoralists in the study sites to acquire land is to purchase a plot of land from relatives. Nevertheless the survey could not explicitly explore to what extent such a system has attributed to land cover changes across the Kebele, but it is among the reasons mentioned during interviews. Moreover, the results further revealed that policy transformation in the 1970s and the intervention of development projects, in particular water projects, were additional factors leading to land use changes. Policy transformations such as privatization of the communal rangelands into private enclosures affected land use and traditional rangeland management and hence expansion of cultivation and the land cover changes [43]. Despite the fact that cultivation is growing in the study locations, there are differences across the sites (Figure 5), and the differences are attributed to the heterogeneous nature of the sites, socio-environmental conditions, availability of draught power (mainly oxen), and variable rainfall. With regard to crops grown in the studied sites, rainfall and soil are the major agro-climatic factors influencing crop performance. Specifically, rain-fed crops such as maize, haricot beans, teff, wheat, 
barley, and sorghum are preferred because of the suitability of the soil and the climate of the area. Apart from being sources of food, they are marketable and, therefore, a reliable source of income for households, and they are also an important source of animal fodder, especially during the dry season.

\section{Conclusions}

In this paper, land cover changes and the reasons behind them have been analyzed in five locations in the Borana rangelands of Southern Ethiopia. Much of the land cover changes differ spatially across the study sites. The most important changes are the loss in the proportion of bushland vegetation in all five sites. Also there are progressive increases in grasslands cover in all sites except Darito. The bare land in the Haralo site is more widely spread than in the rest of the sites, which is an indication of land degradation in this study. Clearing of vegetation, harvesting wood trees for numerous uses (charcoal, fuel wood, fencing, and construction), and the expansion of cultivation activities are instrumental causes of rangeland fragmentation. A bush clearing program has also contributed to the decline in bushland vegetation. Unwise use of rangelands can set processes into motion that drive range degradation and lead to a deterioration of the capacity to store and sequester carbon. Rangelands store carbon as plant biomass and soil organic carbon, and the largest stock is the soil pool because the ecosystem is characterized by scant vegetation. Therefore, converting these ecosystem into croplands without due consideration of their nature potentially undermines their resilience. The land management practices adopted are not adequate to enhance carbon storage potentials. The adoption of no-till farming, water harvesting, and soil conservation and the use of compost manure are very crucial in soil conservation, nutrient restoration, carbon storage, and greenhouse gas mitigation. Conversely, these practices are only moderately adopted. The trade-offs of converting rangelands into cropland without appropriate management are a threat, as they lead to vegetation fragmentation, restriction of livestock mobility, acceleration of soil erosion and loss of soil organic carbon and, hence, land degradation.

Concerning the drivers behind the expansion of cultivation, interactive factors such as recurrent drought, diminished grazing pasture, food insecurity, and the need to diversify income, are possible reasons. A significant association between larger family size and families with school-going children was the main socio-economic and demographic factor attributed to the expansion of cultivation across the study sites. Although access to land is issued by the government, spontaneous encroachment upon rangelands for cultivation purposes remains the critical challenge. Policy transformations and the introduction of private enclosures in the Borana rangeland are other underlying causes leading to the expansion of crop cultivation. The findings of this study have provided a comprehensive insight into the temporal increase in the number agro-pastoralists, current trends in land cover changes, and their impacts on the ecosystem. The retrospective analysis of the drivers behind the expansion of cultivation has established site-specific evidence regarding how environmental, socio-economic, and demographic factors have concurrently contributed to the expansion of crop cultivation. This information is very crucial for future management plans and decisions.

Based on the results of our study, the following recommendations are given. There is a need to incorporate indigenous and scientific information for sustainable rangeland management. There is a large need for addressing the socio-economic and environmental challenges of the local areas as part of a solution to the surface problem of the expansion of cultivation in rangelands. This could be achieved 
through consistent cooperation of policy makers, local resource users, regional and international stakeholders as well as NGOs. In future studies, the analysis of the biophysical changes in the soil quality within cropped areas and that of the natural rangelands is needed. It is also necessary to further investigate the influences of biophysical and agro-climatic factors on land use and land cover changes. Analyzing vegetation changes using multi-temporal satellite data is highly recommended. As a last point, the assessment of emissions through land use can justify the impacts of cultivation on nutrient matter fluxes in rangeland ecosystems.

\section{Acknowledgments}

We acknowledge Folkard Asch for his technical advice on data collection in the field and Margareta Amy Lelea for proofreading the manuscript before submission.

\section{Author Contributions}

Michael Elias and Christian Hülsebusch undertook the fieldwork data collection, statistical analyses, and geo-spatial analysis; Oliver Hensel, Oliver Wasonga, Brigitte Kaufmann, and Uwe Richter provided a critical review of the manuscript before submissions.

\section{Conflicts of Interest}

The authors declare no conflict of interest.

\section{References}

1. Turner, B.L. Toward integrated land-change science: Advances in 1.5 decades of sustained international research on land-use and land-cover change. In Challenges of a Changing Earth; Steffen, W., Jäger, J., Carson, D.J., Bradshaw, C., Eds.; Springer: Berlin, Germany, 2002; pp. 21-26.

2. Camill, P. Global change: An overview. Nat. Educ. Knowl. 2010, 3, 49. Available online: http://www.nature.com/scitable/knowledge/library/global-change-an-overview-13255365 (accessed on 10 November 2012).

3. Lambin, E.F.; Serneels, S. Proximate causes of land-use change in Narok District, Kenya: A spatial statistical model. Agric. Ecosyst. Environ. 2001, 85, 65-81.

4. Geist, H.J.; Lambin, E.F. Proximate causes and underlying driving forces of tropical deforestation. Bioscience 2002, 52, 143-150.

5. Lambin, E.F.; Geist, H.J. Land-use and Land-cover Change: Local Processes and Global Impacts; IGBP Series; Springer-Verlag: Berlin, Germany, 2006; pp. 1-8.

6. Homewood, K.; Coast, E.; Thompson, M. In-migrants and exclusion in East African rangelands: Access, tenure and conflict. Africa 2004, 74, 567-610.

7. Hein, L.; De Ridder, N. Desertification in the Sahel: A reinterpretation. Glob. Chang. Biol. 2006, $12,751-758$.

8. Wessels, K.J.; Prince, S.D.; Malherbe, J.; Small, J.; Frost, P.E.; VanZyl, D. Can human-induced land degradation be distinguished from the effects of rainfall variability? A case study in South Africa. J. Arid Environ. 2007, 68, 271-297. 
9. Kaspersen, P.S.; Fensholt, R.; Huber, S. A spatiotemporal analysis of climatic drivers for observed changes in Sahelian vegetation productivity (1982-2007). Int. J. Geophys. 2011, 2011, $1-14$.

10. WRI. Drylands, People, and Ecosystem Goods and Services: A Web-Based Geospatial Analysis; White, R.P., Nackoney, J., Eds.; World Resources Institute: Washington, DC, USA, 2003; pp. 1-58.

11. Safriel, U.; Adeel, Z.; Niemeijer, D.; Puigdefabregas, J.; White, R.; Lal, R.; Wilson, M.; Ziedler, J.; Prince, S.; Archer, E.; et al. Dry land systems. In Ecosystems and Human Well-being: Current State and Trends; Hassan, R., Scholes, R., Ash, N., Eds.; World Resource Institute: Washington, DC, USA, 2005; pp. 625-653.

12. White, R.P.; Wanasselt, W. Grasslands in Pieces: Modification and Conversion Take a Toll; World Resource Institute: Washington, DC, USA, 2000; pp. 1-4.

13. Garedew, E. Land Use and Land Cover Dynamics and Rural Livelihood Perspectives in the Semi-Arid Areas of Central Rift Valley of Ethiopia. Ph.D. Thesis. Swedish University of Agricultural Sciences, Umeå, Sweden, 2010.

14. Flintan, F. The Causes, Process and Impacts of Land Fragmentation in the Rangelands of Ethiopia, Kenya and Uganda: Regional Learning and Advocacy Programme for Vulnerable Dryland Communities, 2011. Available online: http://www.preventionweb.net/files/24288_ 24288summarybrieflandfragmentationf.pdf (accessed 5 September 2012).

15. Coppock, D.L. The Borana Plateau of Southern Ethiopia: Synthesis of Pastoral Research, Development and Change, 1980-91; International Livestock Centre for Africa: Addis Ababa. Ethiopia, 1994; p. 393.

16. Oba, G.; Post, E.; Syvertsen, P.O.; Stenseth, N.C. Bush cover and range condition assessments in relation to landscape and grazing in southern Ethiopia. Landsc. Ecol. 2000, 15, 535-546.

17. Tache, B.; Oba, G. Is poverty driving Borana herder in southern Ethiopia to crop cultivation? Hum. Ecol. 2010, 38, 639-649.

18. Tolera, A.; Abebe, A. Livestock production in pastoral and agro-pastoral production systems of southern Ethiopia. Livest. Res. Rural Dev. 2007, 19, 177. Available online: http:/www.lrrd.org/ 1rrd19/12/tole19177.htm (accessed on 29 December 2014).

19. Solomon, T.B.; Snyman, H.A.; Smit, G.N. Cattle-rangeland management practices and perceptions of pastoralists towards rangeland degradation in the Borana zone of southern Ethiopia. J. Environ. Manage. 2007, 82, 481-494.

20. Desta, S.; Coppock, D.L. Pastoralism under pressure: Tracking system change in southern Ethiopia. Human Ecology. 2004, 32, 485-486.

21. Liavoga, B.A.; Kathumo, V.M.; Onwonga, R.N.; Karuku, G.N.; Onyango, C.M. Assessment of trends in land cover and crop type change over two decades in Yatta sub county, Kenya. Int. J. Agric. For. Fish. 2014, 2, 46-52.

22. Foody, G.M. Status of land cover classification accuracy assessment remote. Sens. Environ. 2002, 80, 185-201.

23. Pisanelli, A.; Chiocchini, F.; Cherubini, L.; Lauteri, M. Combining demographic and land-use dynamics with local communities perceptions for analysing socio-ecological systems: A case study in a mountain area of Italy. iForest 2012, 5, 163-170. 
24. Mengistu, A. The Borana and the Drought: A Rangeland and Livestock Resource Study; Institute of Sustainable Development: Addis Ababa, Ethiopia, 1998; pp. 1-79.

25. Tefera, S.; Snyman, H.A.; Smit, G.N. Rangeland dynamics in southern Ethiopia: (1) botanical composition of grasses and soil characteristics in relation to land-use and distance from water in semi-arid Borana rangelands. J. Environ. Manage. 2007, 85, 429-442.

26. Ethiopian Mapping Agency. Topographical Maps of Yabelo (1992) and Mega (1993); Ethiopian Mapping Agency: Addis Ababa, Ethiopia, 2012.

27. Ethiopian Meteorological Agency. Recorded Rainfall and Temperature Data of Yabelo and Dire Districts in Borana Rangeland; Ethiopian Meteorological Agency: Addis Ababa, Ethiopia, 2012. Unpublished data.

28. Lillesand, T.M.; Keifer, R.W.; Chipman, J.W. Remote Sensing and Image Interpretation: Digital Image Interpretation and Analysis; John Wiley \& Sons: Hoboken, NJ, USA, 2008; pp. 482-621.

29. Anderson, A. Land Use and Land Cover Classification System; Geological Survey Professional Paper 964, USGS: Washington, DC, USA, 1976.

30. Pratt, D.J.; Greenway, P.J.; Gwynne, M.D. A classification of East Africa rangeland, with an appendix on terminology. J. Appl. Ecol. 1966, 3, 369-383.

31. Pratt, D.J.; Gwynne, M.D. Rangeland Management and Ecology in East Africa; Hodder and Stoughton: London, UK, 1977.

32. Haile, G.; Assen, M.; Ebro, A. Land use/cover dynamics and its implications since the 1960s in the Borana rangelands of Southern Ethiopia. Livestock Research for Rural Development 2010, 22, 132. Available online: http://www.lrrd.org/lrrd22/7/hail22132.htm (accessed on 8 March 2013).

33. Wezel, A.; Haigis, J. Farmers' perception of vegetation changes in semi-arid Niger. Land Degrad. Dev. 2000, 11, 523-534.

34. Tsegaye, D.; Moe, S.R.; Vedeld, P.; Aynekulu, E. Land-use/cover dynamics in Northern Afar rangelands, Ethiopia. Agric. Ecosyst. Environ. 2010, 139, 174-180.

35. Guo, L.; Gifford, R. Soil carbon stocks and land use change: A meta-analysis. Global Change Biol. 2002, 8, 345-360.

36. Lal, R. Soil carbon sequestration to mitigate climate change. Geoderma 2004, 123, 1-22.

37. Trumper, K.; Ravilious, C.; Dickson, B.A. Carbon in drylands: desertification, climate change and carbon finance. A UNEP-UNDP-UNCCD technical note for discussions. In Proceedings of the Seventh Session of the Committee for the Review of the Implementation of the Convention (CRIC 7), Istanbul, Turkey, 3-14 November 2008.

38. Neely, C.; Bunning, S.; Wilkes, A. Review of Evidence on Drylands Pastoral Systems and Climate Change: Implications and Opportunities for Mitigation and Adaptation; Land and Water Discussion Paper 8; FAO: Rome, Italy, 2009; pp. 1-33.

39. Reid, R.S.; Thornton, P.K.; McCrabb, G.J.; Kruska, R.L.; Atieno, F.; Jones, P.G. Is it possible to mitigate greenhouse gas emissions in pastoral ecosystems of the tropics. Environ. Dev. Sustain. 2004, 6, 91-109.

40. Seleshi, Y.; Zanke, U. Recent changes in rainfall and rainy days in Ethiopia. Int. J. Climatol. 2004, 24, 973-983.

41. Lambin, E.F.; Geist, H.J.; Lepers, E. Dynamics of land-use and land cover change in tropical regions. Ann. Rev. Environ. Resour. 2003, 28, 205-241. 
42. Yemane, B. Drought and famine in the pastoral areas of Ethiopia (Oxfam GB). In Pastoralist Forum Ethiopia; Admassu, Y., Ed.; Pastoralist Forum Ethiopia: Addis Ababa, Ethiopia, 2004; pp. 117-134.

43. Angassa, A.; Oba, G. Herder perception on impacts of range enclosures, crop farming, fire ban and bush encroachment on the rangeland of Borana, Southern Ethiopia. Hum. Ecol. 2008, 36, 201-215.

44. Campbell, D.J.; Lusch, D.P.; Smucker, T.A.; Wangu, E.E. Multiple methods in the study of driving forces of land use and land cover change: A case study of South East Kajiado district Kenya. Hum. Ecol. 2005, 33, 763-794.

45. Wasonga, V.O.; Nyariki, D.M.; Ngugi, R.K. Assessing socio-ecological dynamics using local knowledge in the semi-arid lowlands of Baringo districts, Kenya. Environ. Res. J. 2011, 5, 11-17.

46. Cheung, W.H.; Senay, G.B.; Singh, A. Trends and spatial distribution of annual and seasonal rainfall in Ethiopia. Int. J. Climatol. 2008, 28, doi:10.1002/joc.1623.

47. Crewett, W.; Bogale, A.; Korf, B. Land Tenure in Ethiopia: Continuity and Change, Shifting Rulers, and the Quest for State Control; CAPRi Working Paper 91; International Food Policy Research Institute: Washington, DC, USA, 2008; pp. 1-22.

(C) 2015 by the authors; licensee MDPI, Basel, Switzerland. This article is an open access article distributed under the terms and conditions of the Creative Commons Attribution license (http://creativecommons.org/licenses/by/4.0/). 